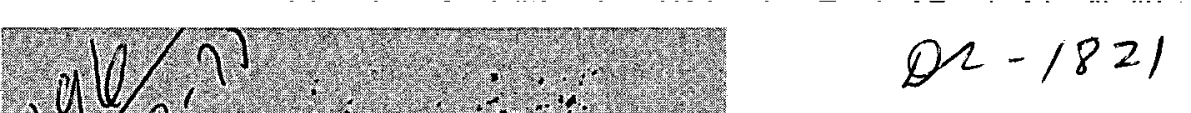

\title{
EFFECT OF AGING ON THE GENERAL CORROSION AND STRESS CORROSION CRACKING OF URANIUM- 6 WT \% NIOBIUM ALLOY
}
J. W. Koger
A. M. Ammons
J. E. Ferguson

November 1975
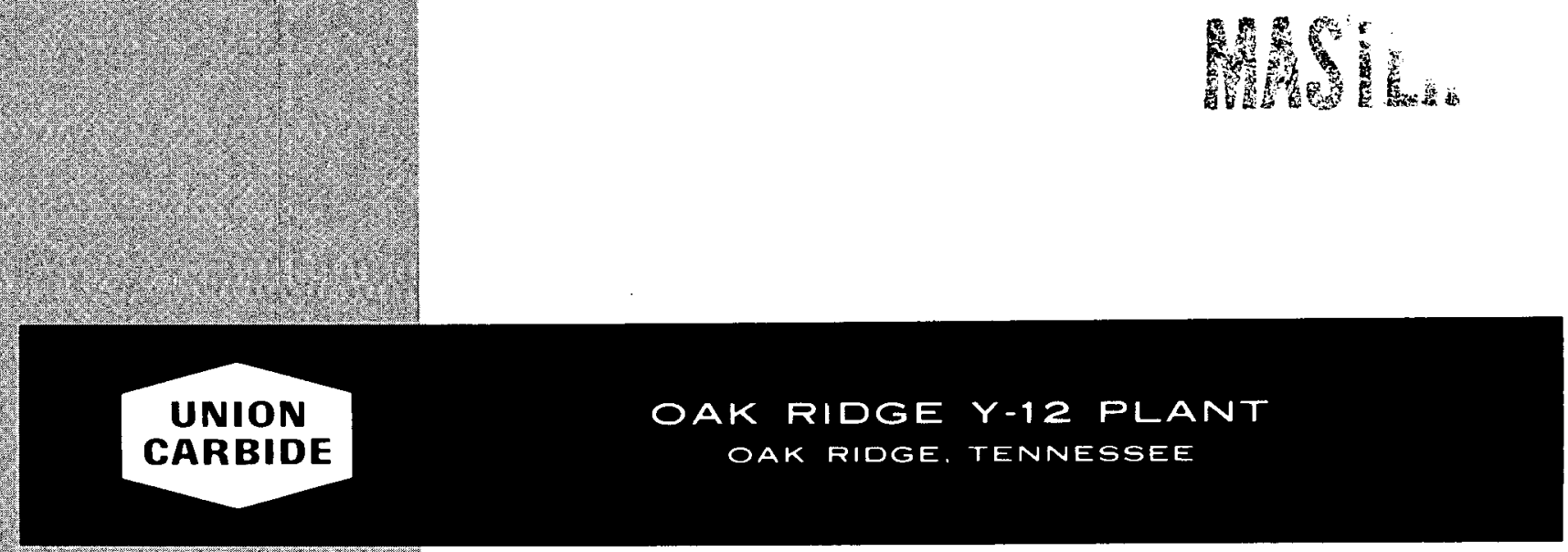

prepared for the U.S. ENERGY RESEARCH AND DEVELOPMENT ADMINISTRATION under U.S. GOVERNMENT Contract W-7405 eng 26 


\section{DISCLAIMER}

This report was prepared as an account of work sponsored by an agency of the United States Government. Neither the United States Government nor any agency Thereof, nor any of their employees, makes any warranty, express or implied, or assumes any legal liability or responsibility for the accuracy, completeness, or usefulness of any information, apparatus, product, or process disclosed, or represents that its use would not infringe privately owned rights. Reference herein to any specific commercial product, process, or service by trade name, trademark, manufacturer, or otherwise does not necessarily constitute or imply its endorsement, recommendation, or favoring by the United States Government or any agency thereof. The views and opinions of authors expressed herein do not necessarily state or reflect those of the United States Government or any agency thereof. 


\section{DISCLAIMER}

Portions of this document may be illegible in electronic image products. Images are produced from the best available original document. 


\begin{abstract}
Reference to a company or product name does not imply approval or recommendation of the product by Union Carbide Corporation or the U.S. Energy Research and Development Administration to the exclusion of others that may meet specifications.
\end{abstract}

Printed in the United States of America. Available from National Technical Information Service

U.S. Department of Commerce

5285 Port Royal Road, Springfield, Virginia 22161

Price: Printed Copy \$4.00; Microfiche $\$ 2.25$

This report was prepared as an account of work sponsored by the United States Government. Neither the United States nor the Energy Research and Development Administration, nor any of their employees, nor any of their contractors, subcontractors, or their employees, makes any warranty, express or implied, or assumes any legal liability or responsibility for the accuracy, completeness or usefulness of any information, apparatus, product or process disclosed, or represents that its use would not infringe privately owned rights. 


\title{
EFFECT OF AGING ON THE GENERAL CORROSION AND STRESS CORROSION CRACKING OF URANIUM-6 WT \% NIOBIUM ALLOY
}

\author{
J. W. Koger \\ A. M. Ammons \\ Metallurgical Development Department \\ J. E. Ferguson \\ Laboratory Development Department \\ Y-12 Development Division
}

NOTICE

This report was prepared as an account of work sponsored by the United States Government. Neither the United States nor the United States Energy Research and Development Administration, nor any of their employees, nor any of their contractors, subcontractors, or their employees, makes any warranty, express or implied, or assumes any legal liability or responsibility for the accuracy, completeness or usefulness of any information, apparatus, product or process disclosed, or represents that its use would not infringe privately owned rights.

Oak Ridge Y-12 Plant

P. O. Box Y, Oak Ridge, Tennessee 37830

Prepared for the US Energy Research

and Development Administration

Under US Government Contract W-7405-eng-26 


\begin{abstract}
Mechanical properties of the uranium- 6 wt \% niobium alloy change with aging time and temperature. In general, the ultimate tensile strength and hardness reach a peak, while elongation becomes a minimum at aging temperatures between 400 and $500^{\circ} \mathrm{C}$. The first optical evidence of a second phase was in the $400^{\circ} \mathrm{C}$-aged alloy, while complete transformation to a two-phase structure was seen in the $600^{\circ} \mathrm{C}$-aged alloy. The maximum-strength conditions correlate with the minimum stress corrosion cracking (SCC) resistance. The maximum SCC resistance is found in the as-quenched and 150, 200, and $600^{\circ} \mathrm{C}$-aged specimens. The as-quenched and $3000 \mathrm{C}$-aged specimens had the greatest resistance to general corrosion in aqueous chloride solutions; the $6000 \mathrm{C}$-aged specimen had the least resistance.
\end{abstract}




\section{CONTENTS}

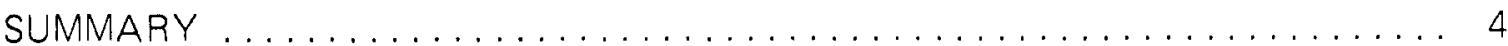

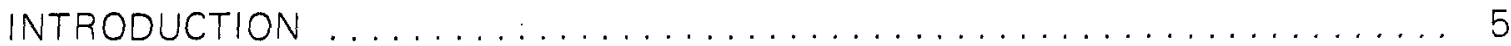

STUDIES OF THE URANIUM-6 NIOBIUM ALLOY ...................6

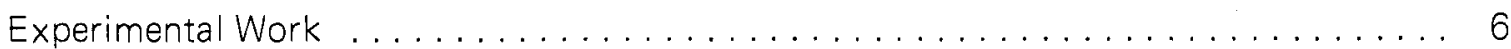

Results and Discussion ..............................

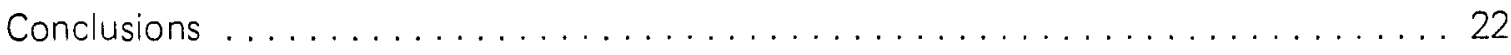

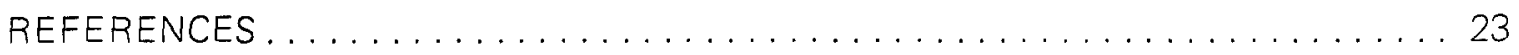




\section{SUMMARY}

A determination was made of the effect of aging on stress corrosion cracking and general corrosion of uranium- 6 wt \% niobium alloy. Stress corrosion was characterized by the time to failure of stressed smooth specimens in aqueous chloride solutions, while general corrosion was determined by potentiostatic methods. The effect of aging was measured in terms of variables in the mechanical properties of the alloy. Optical and scanning electron microscopy and $X$-ray diffraction analysis were also used for characterization. 


\section{INTRODUCTION}

Many studies have been conducted on the uranium-niobium alloy system, and an excellent review has been given by Jackson. (1)

The work discussed in this report, performed at the Oak Ridge Y-12 Plant, (a) was focused mainly on the stress corrosion cracking (SCC) and aging characteristics of the uranium- 6 wt $\%$ niobium alloy $(\mathrm{U}-6 \mathrm{Nb})$. In the experiments described herein, the susceptibility to SCC was measured as the time to failure of unnotched specimens under stress. (The time included both nucleation and growth of the SCC.) It is felt that the time-to-failure method is quite useful and complements the data obtained from methods which involve the concepts of fracture mechanics and where the growth rate of a stress corrosion crack is measured as a function of the stress intensity factor of KISCC. It was the purpose of this investigation to systematically determine the time to failure and the general corrosion characteristics of the U-6 Nb alloy (aged at different temperatures) as a function of stress, applied potential, $\mathrm{pH}$, and chloride content, and to determine the effect of the aging time on the various mechanical properties of the alloy.

(a) Operated by the Union Carbide Corporation's Nuclear Division for the US Energy Research and Development Administration. 


\section{STUDIES OF THE URANIUM-6 NIOBIUM ALLOY}

\section{EXPERIMENTAL WORK}

Strips of the component metals were fabricated into consumable arc-melt electrodes which were melted into a water-cooled copper mold. Five single-arc-melt ingots were cropped, inverted, and welded end to end into a single electrode for remelting. The double-arc-melt ingot $(180 \mathrm{~mm}$ D) was skinned to remove surface defects and cut into cylindrical billets, $230 \mathrm{~mm}$ long. The billets were heated to $850^{\circ} \mathrm{C}$ and upset forged in the axial direction to a height of $40 \mathrm{~mm}$. The forgings were homogenized for 10 hours at $1000^{\circ} \mathrm{C}$ in vacuum. Subsequently, they were round rolled ( $45^{\circ}$ rotation of the rolling direction between passes) to a 1.6-mm thickness. The plates were then heat treated for one hour at $800^{\circ} \mathrm{C}$ and water quenched. Low-temperature aging was done in a circulating air furnance; while, at higher temperatures, a vacuum furnace was used to prevent oxidation. Before any corrosion tests, all specimens were degreased with acetone and rinsed with ethanol.

Solutions used were prepared from laboratory reagent-grade chemicals and deionized water. The buffers used included acetic acid, potassium hydrogen phthalate, and sodium hydroxide. Polarization measurements were made on specimens in water containing only these buffers to assess the effect of the buffers. No corrosive or inhibitive effects were noted.

The electrochemical cells were either of glass or polyethylene. Platinum was used as the counter electrode. Potentials were measured using an $\mathrm{Ag} / \mathrm{AgCl}$ or Calomel reference electrode. The electronic potentiostat used was designed and built at the Oak Ridge National Laboratory (Figure 1).

Test methods used to determine the SCC characteristics of a particular system involved exposing bend or tensile-type specimens, to which a potential could be applied, to chloride solutions. The bend specimens were stressed in constant-deflection, four-point bend fixtures made of Plexiglas. The electrochemical cell setup with a bend specimen is seen in Figure 2 . Several fixtures which could provide a variety of strains were available. The strains provided by the fixtures were calculated and the values obtained compared favorably to strain-gage measurements on specimens held in the fixtures. The bend specimens were $125 \mathrm{~mm}$ long by $13 \mathrm{~mm}$ wide by $2 \mathrm{~mm}$ thick.

Reproducibility of the data for this size specimen was quite good. An acoustic emission detector was also attached to the specimen during the SCC tests. The detector was an Aerotech piezoelectric transducer. The acoustic pulse was amplified with a $60-\mathrm{db}, 10^{-6}$ to 1 $\mathrm{MHz}$ amplifier and was high-pass filtered at $5000 \mathrm{kHz}$ to remove extraneous background pickup. A record was made of the number of acoustic pulses passing above a 0.2-volt threshold each second. Along with the acoustic pulses, the current resulting from the applied potential, the time of the first appearance of a visible surface crack, and the time for complete failure was also noted and recorded.

The tensile-type specimen was $125 \mathrm{~mm}$ long by $5 \mathrm{~mm}$ wide by $2.5 \mathrm{~mm}$ thick in the reduced area. These specimens were placed in a Plexiglas environmental cell (Figure 3) and tested under a constant uniaxial load (Figure 4). After the test, specimens were subsequently examined both by optical and scanning electron microscopy. 


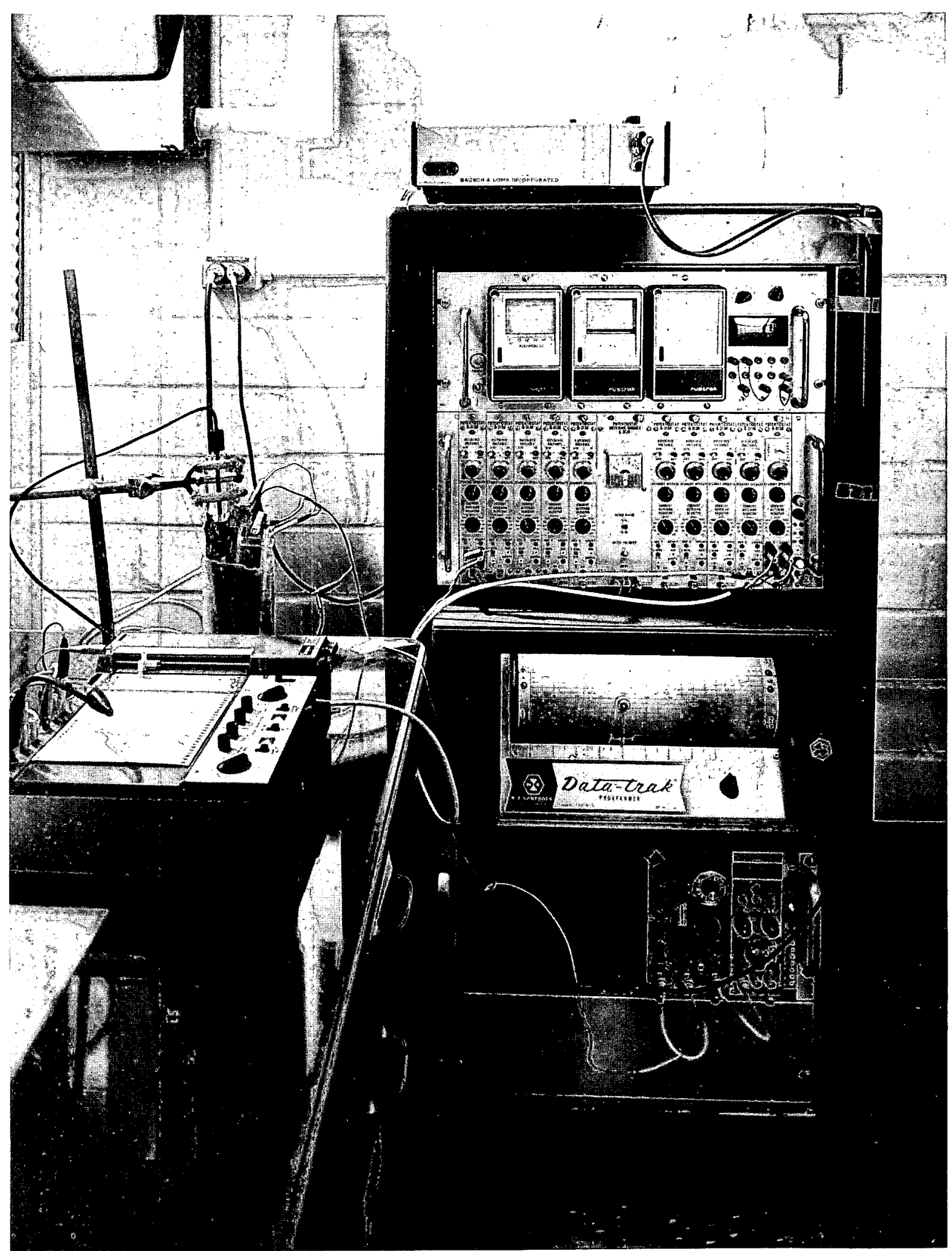

158057

Figure 1. ELECTRONIC POTENTIOSTAT, DATA-TRAK PROGRAMMER, X.Y RECORDER, AND ELECTROCHEMICAL CELL. 


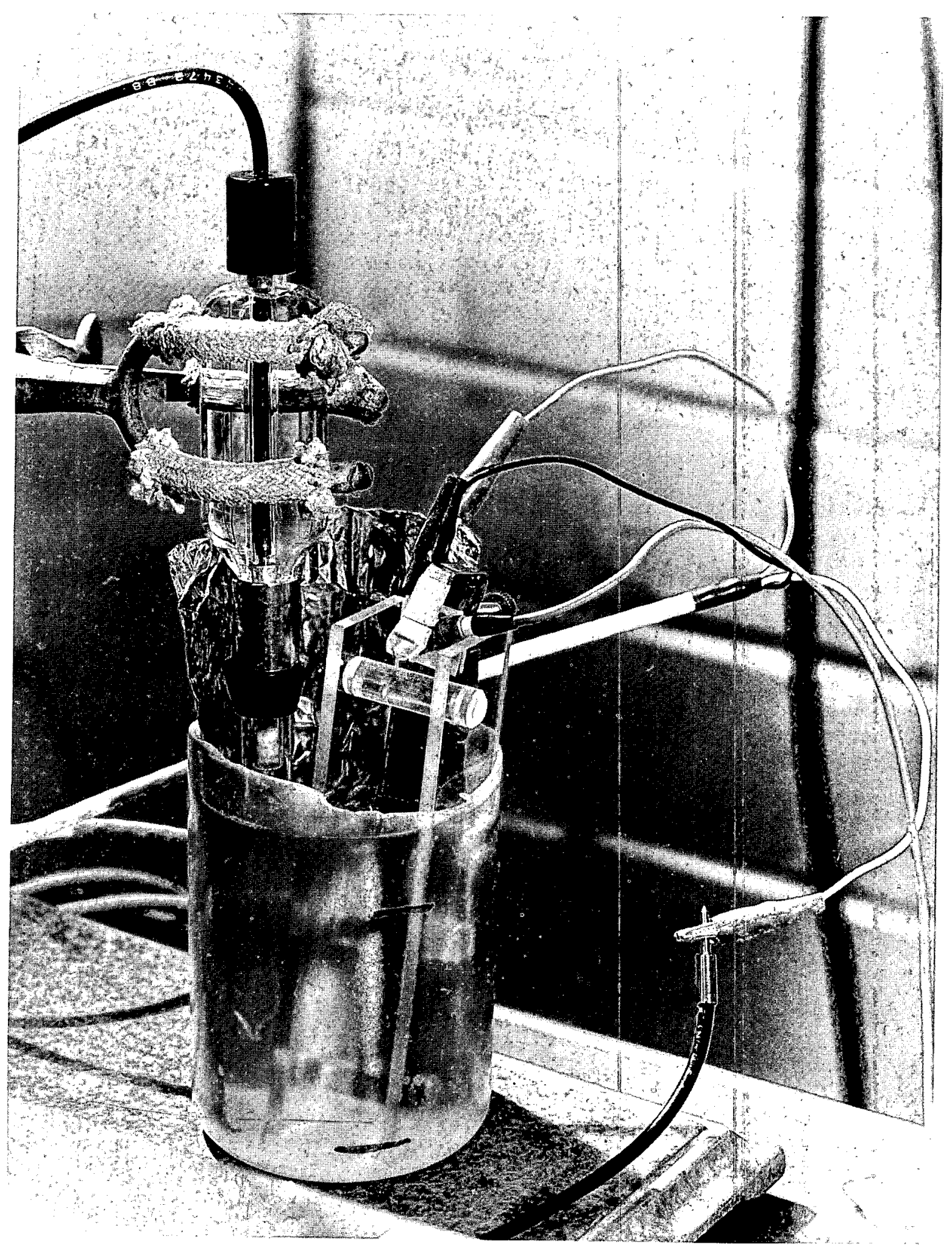

158054

Figure 2. ELECTROCHEMICAL CELL WITH A BEND SPECIMEN IN PLACE. 


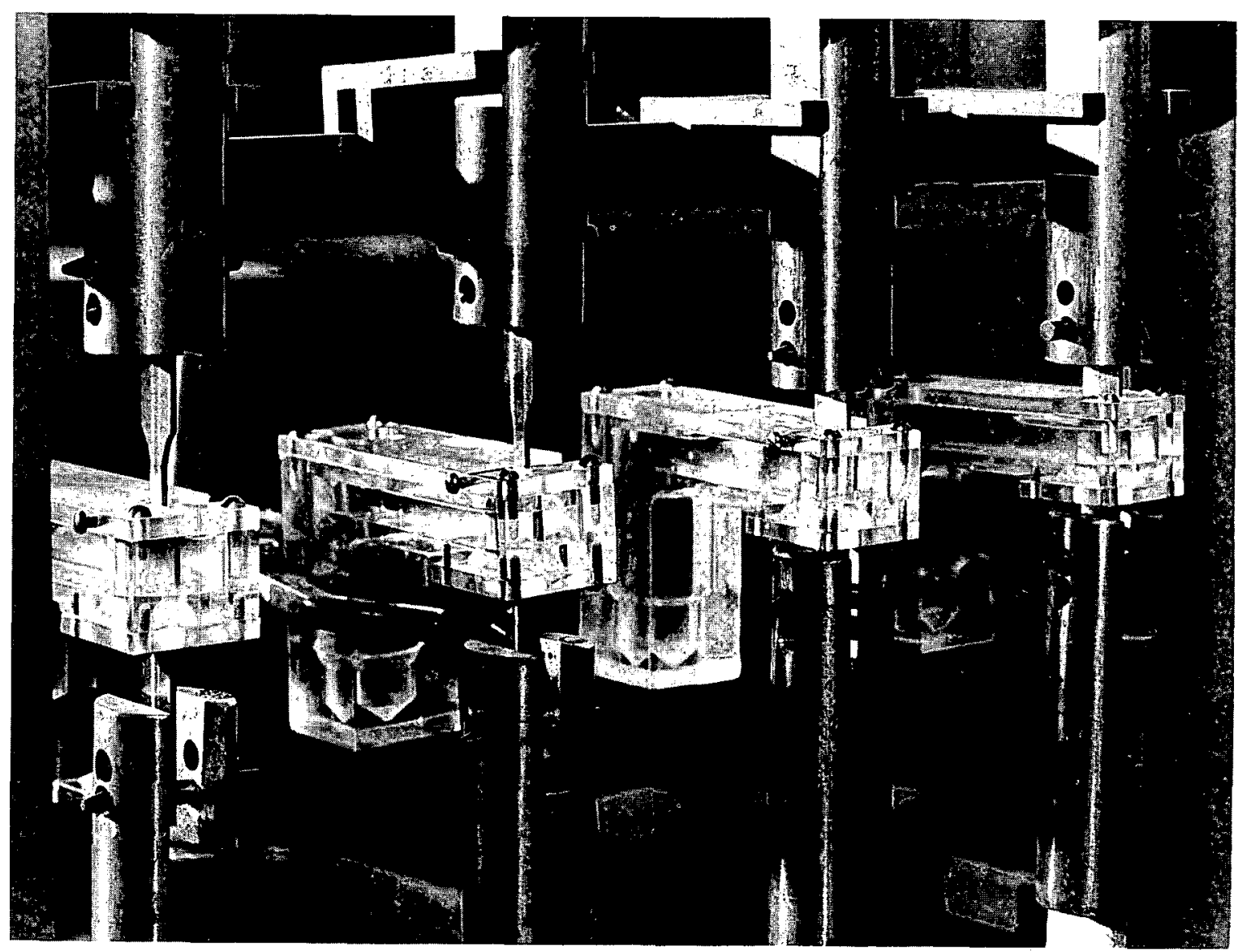

158056

Figure 3. PLEXIGLAS ENVIRONMENTAL CELL FOR TENSILE-TYPE STRESS-CORROSION SPECIMENS.

The open-circuit potential (initial corrosion potential) was obtained for each system before applying a potential. The open-circuit potential was monitored up to 30 minutes, by which time it was normally constant. Polarization curves were obtained for unstressed specimens in the various chloride systems. The potential was varied from -900 to $+900 \mathrm{mV} v \mathrm{Ag} / \mathrm{AgCl}$ standard electrode, and the change in current monitored. The scanning rate was about $4 \mathrm{~V} / \mathrm{hr}$.

\section{RESULTS AND DISCUSSION}

In order to acquire baseline data on this particular alloy, the mechanical properties and hardness values were determined for the alloy samples that were vacuum water quenched from 800, 850, and $900^{\circ} \mathrm{C}$ and aged at 200,300,400,500, and $600^{\circ} \mathrm{C}$ for various times after an $800^{\circ} \mathrm{C}$ vacuum water quench. Figures 5 through 7 report data on the various mechanical properties and hardnesses for several aging temperatures at times of 2, 4, and 8 hours, respectively. As indicated, on aging for 2 and 4 hours, the tensile strength and hardness increased through the $500^{\circ} \mathrm{C}$ aging temperature; on aging for 2, 4, and 8 hours, the yield strength $(0.2 \%$ offset) increased and the reduction in area and elongation decreased through the $400^{\circ} \mathrm{C}$ aging temperature, then each changed direction. There was almost no elongation of the alloy that was aged at 400 or $500^{\circ} \mathrm{C}$. On aging for 8 hours, the tensile 


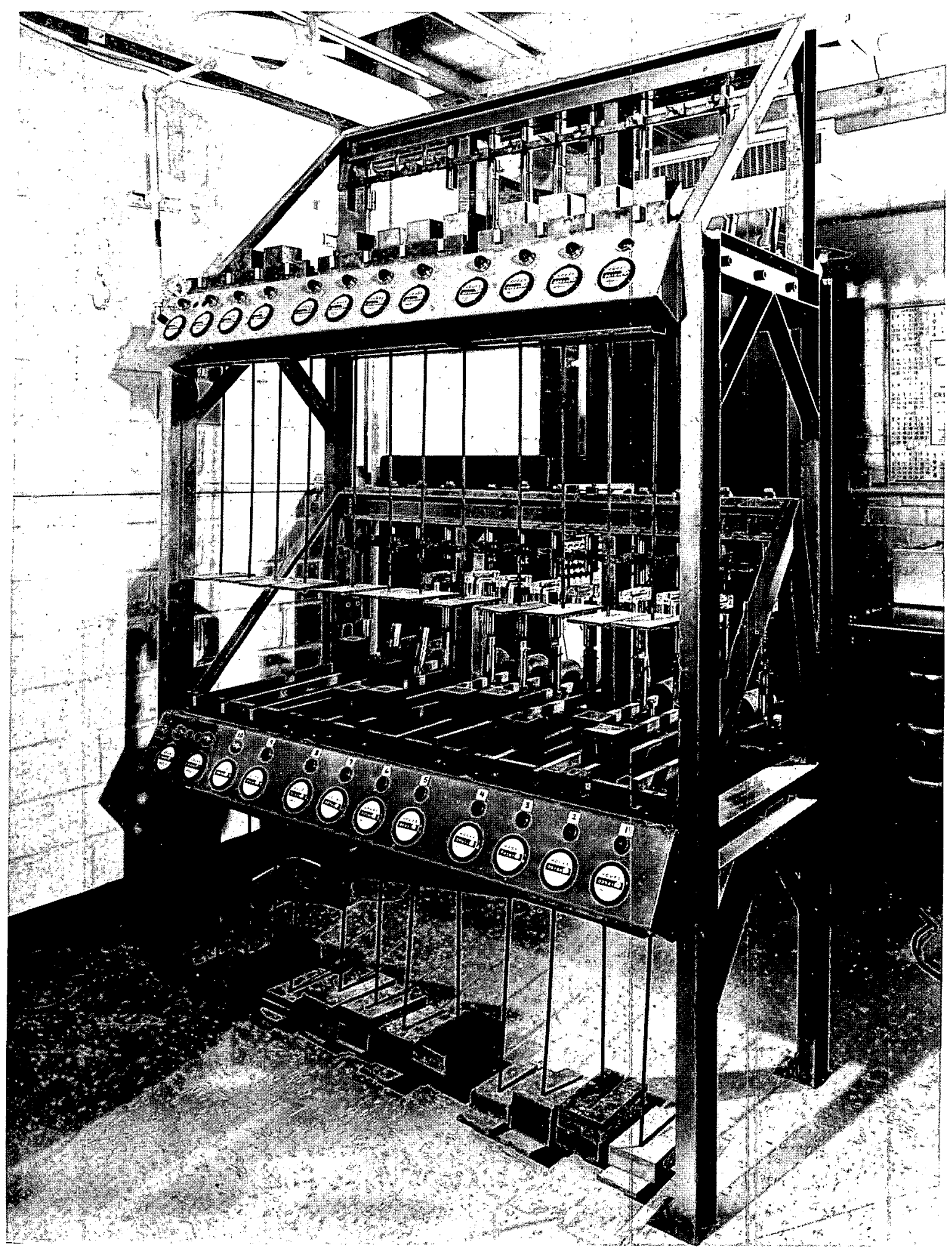

Figure 4. CONSTANT-LOAD MACHINE FOR THE STRESS-CORROSION-CRACKING TESTING OF TENSILE-TYPE SPECIMENS. 


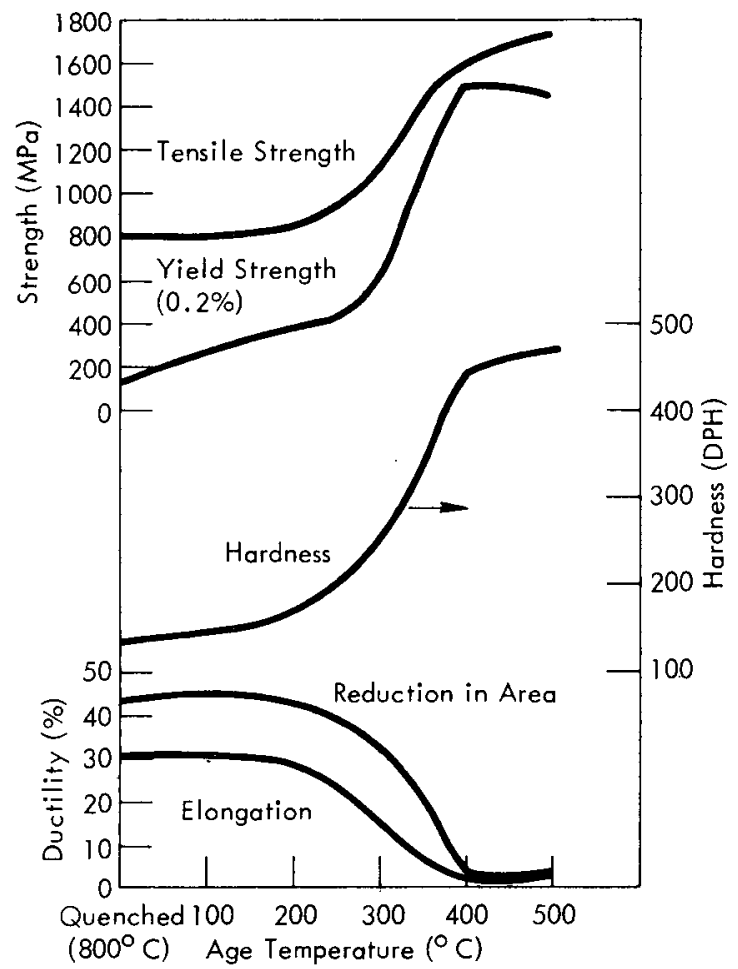

Figure 5. MECHANICAL PROPERTIES AND HARDNESS OF URANIUM-6 NIOBIUM SAMPLES. (Aged for 2 Hours at Various Temperatures)

strength and hardness decreased after the $400^{\circ} \mathrm{C}$ aging temperature. Jackson, et al (2) report that for a one-hour age at the various temperatures, the maximum tensile strength and $0.2 \%$ yield strength occurred on specimens aged at $500^{\circ} \mathrm{C}$. They noted very little elongation or reduction in area at aging temperatures between 400 and $475^{\circ} \mathrm{C}$. The hardness maximum of their specimens was found between aging temperatures of 400 and $450^{\circ} \mathrm{C}$.

In the $200^{\circ} \mathrm{C}$-aged series (Figure 8), the hardness increased as the aging time increased through 24 hours, then gradually decreased. Tensile strength changed very little with the aging time; perhaps, gradually increasing. Yield strength $(0.2 \%$ offset $)$ continually increased with the aging time. The percent elongation essentially remained constant for an eight-hour aging, then decreased with longer aging times. The percent reduction in area increased in four hours of aging, then decreased with longer

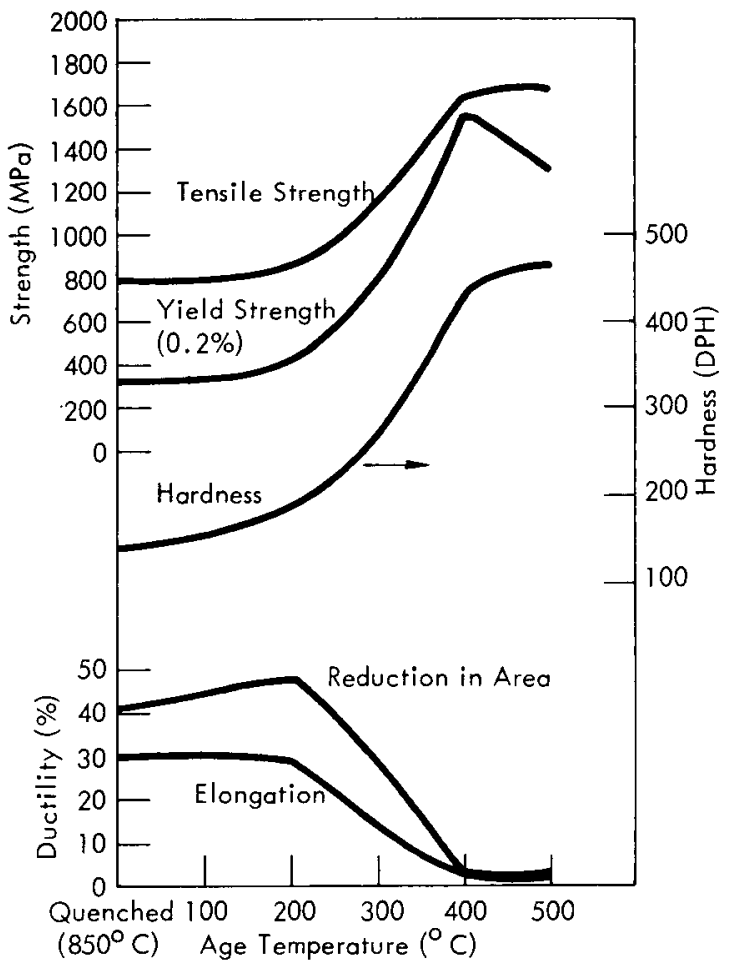

Figure 6. MECHANICAL PROPERTIES AND HARDNESS OF URANIUM-6 NIOBIUM SAMPLES. (Aged for 4 Hours at Various Temperatures)

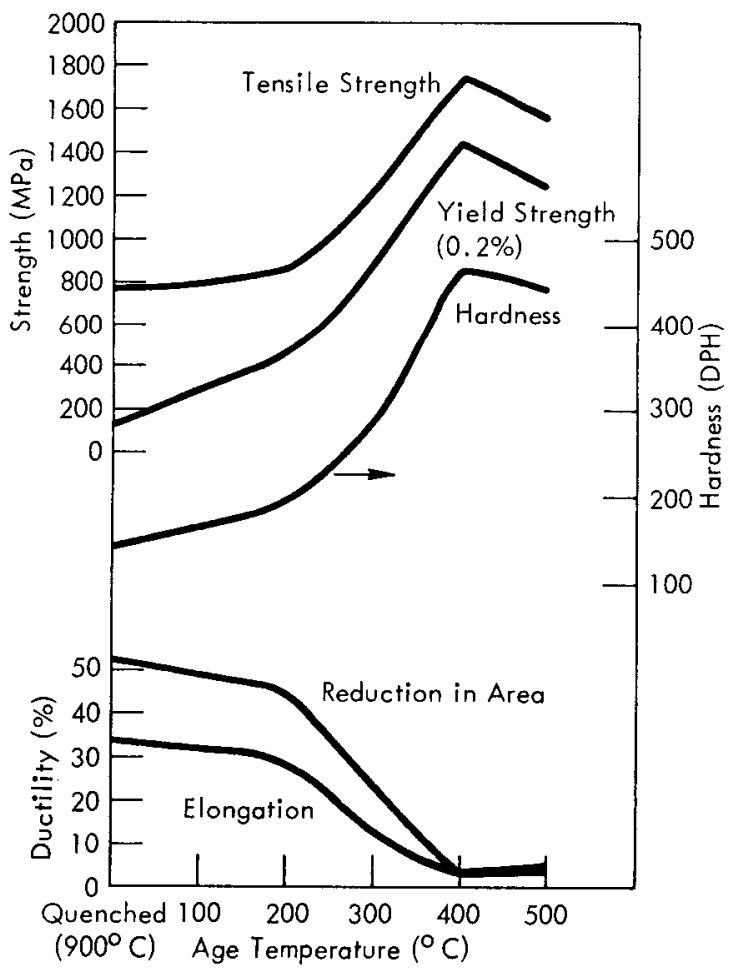

Figure 7. MECHANICAL PROPERTIES AND HARDNESS OF URANIUM-6 NIOBIUM SAMPLES. (Aged for 8 Hours at Various Temperatures) 


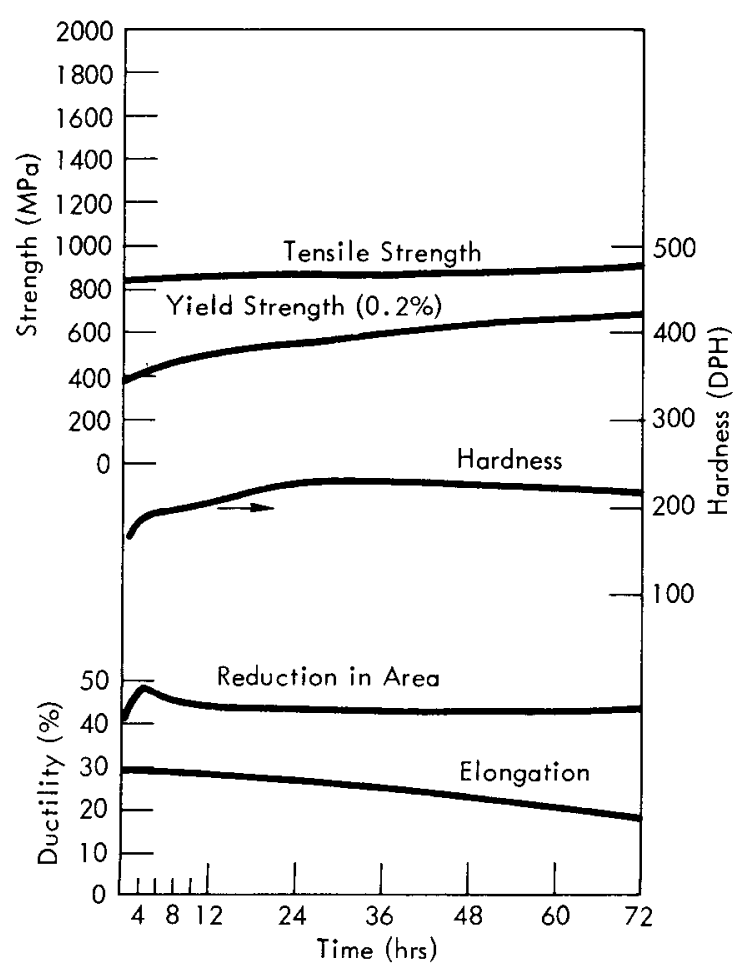

Figure 8. MECHANICAL PROPERTIES AND HARDNESS OF URANIUM-6 NIOBIUM SAMPLES. (Aged at $200^{\circ}$ C for Various Times) aging times. Jackson, et al(2) noted a near $50 \%$ increase in the yield strength and a $40 \%$ increase in the reduction in area after aging at $150^{\circ} \mathrm{C}$ for 6 hours. The ultimate tensile strength decreased. Figure 9 gives the optical microstructure for the $200^{\circ} \mathrm{C}$-aged specimens at the various aging times. Little, if any, difference is noted in any of the single-phased structures.

At a $300^{\circ} \mathrm{C}$ aging temperature (Figure 10), the hardness, tensile strength, and yield strength $(0.2 \%$ offset) increased, while the percent elongation and percent reduction in area decreased with the aging time. The optical microstructures showing single-phase structures are presented in Figure 11. Again, little difference in structure with aging time is seen. The $100^{\circ} \mathrm{C}$ increase in the aging temperature (from 200 and $300^{\circ} \mathrm{C}$ ) had more effect on the properties than the 72-hour aging at $200^{\circ} \mathrm{C}$.

In the $400^{\circ} \mathrm{C}$-aged series (Figure 12), increased aging times had a minimal effect on the various properties. Optical microstructures, showing precipitation at the grain boundaries, are seen in Figure 13. An increased amount of second phase is noted as the aging time increases. Jackson, et al (2) also noted that a sample aged for one hour at $350^{\circ} \mathrm{C}$ showed decomposition of the original structure, and that a sample aged for one hour at $400^{\circ} \mathrm{C}$ showed some localized precipitation at the grain boundaries.

In the $500^{\circ} \mathrm{C}$-aged series (Figure 14), increased aging caused the hardness and the tensile and yield $(0.2 \%$ offset) strengths to generally decrease, but this treatment had very little effect on the percents of elongation and reduction in area, which were very small at the start. The optical microstructures, given in Figure 15, show evidence of the second precipitated phase, but differ little from one aging time to the next. As Jackson also found, unresolvable matrix and islands of partly decomposed metastable parent phase were observed. Aging at $600^{\circ} \mathrm{C}$ produced an almost completely transformed two-phase pearlitic structure, which is noted in Figure 16.

In the 800,850 , and $900^{\circ} \mathrm{C}$ vacuum-water-quench series, the increasing temperature caused an increase in hardness, a decrease in both the tensile and yield (0.2\% offset) strengths, and a general increase in the percents of elongation and reduction in area. Optical micrographs (Figure 17), show increasing grain size with increasing temperature.

This report does not include the mechanistic studies. They will follow in later reports. However, some explanation of the probable effects will be given. 


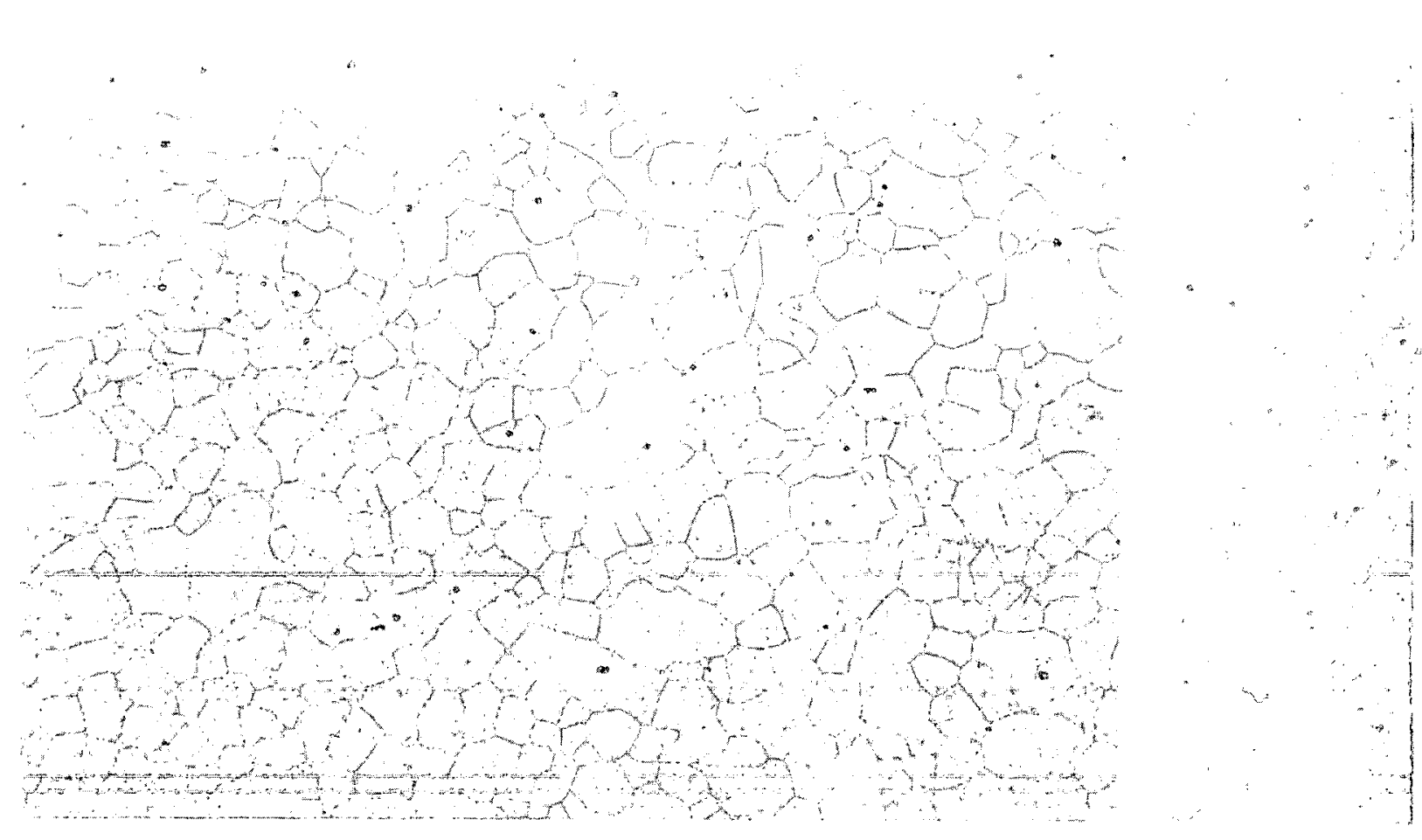

(a) For 2 Hours.

MS-74-0827-2 (b) For 4 Hours.

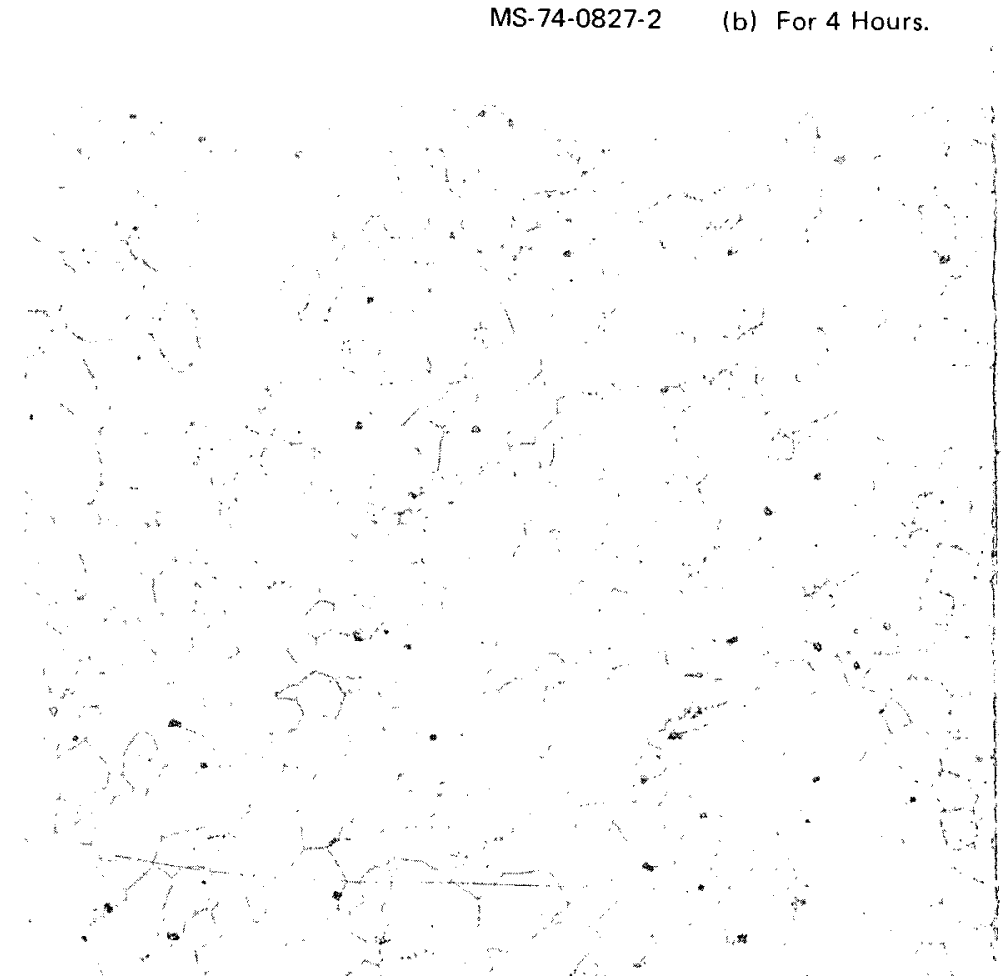

(d) For 24 Hours.

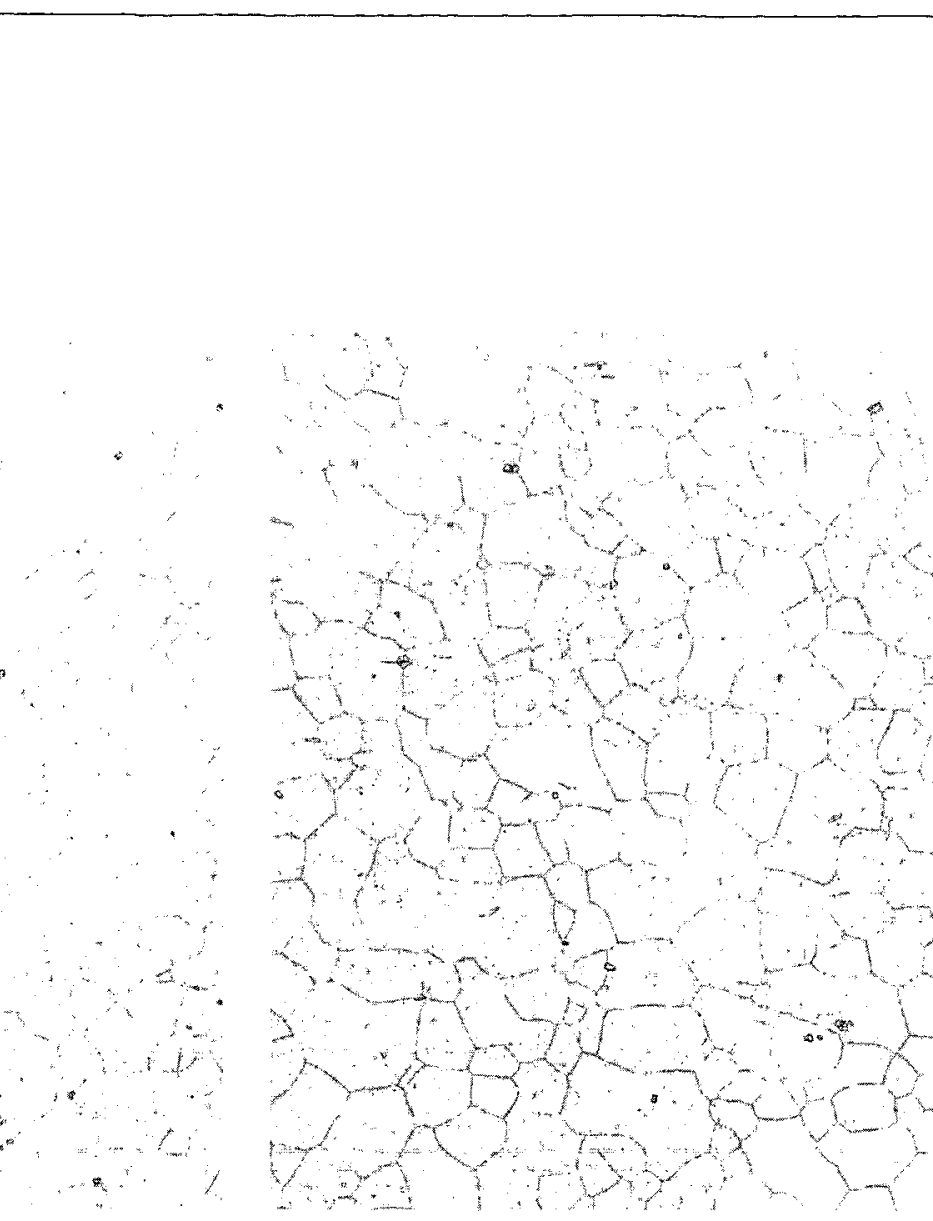

MS.74.0827.3 (c) For 8 Hours.

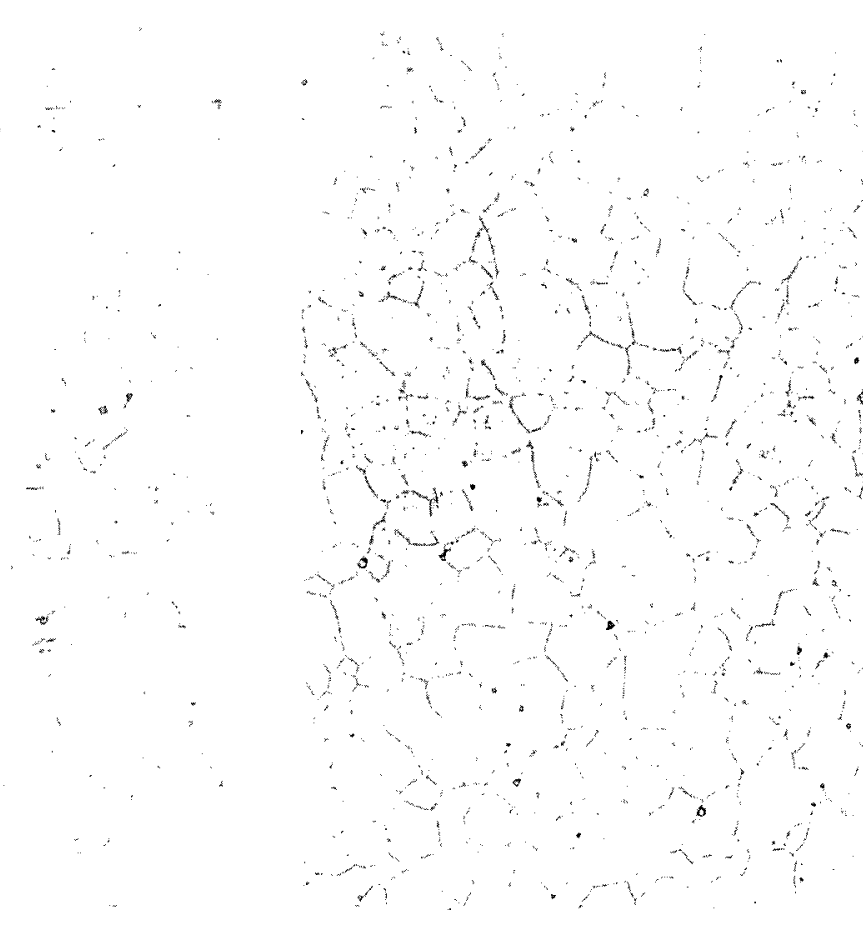

$\operatorname{ms} 7408275$ (e) for 72 touss.

Eigure 9. URANIUM. 6 NIOB IUM SAMPLES THAT WERE VACUUM-WATER OUENCHED FROM $800^{\circ} \mathrm{C}$ AND AGED AT $200^{\circ} \mathrm{C}$ FOR VARIOUS TIMES, $1000 \mathrm{X}$

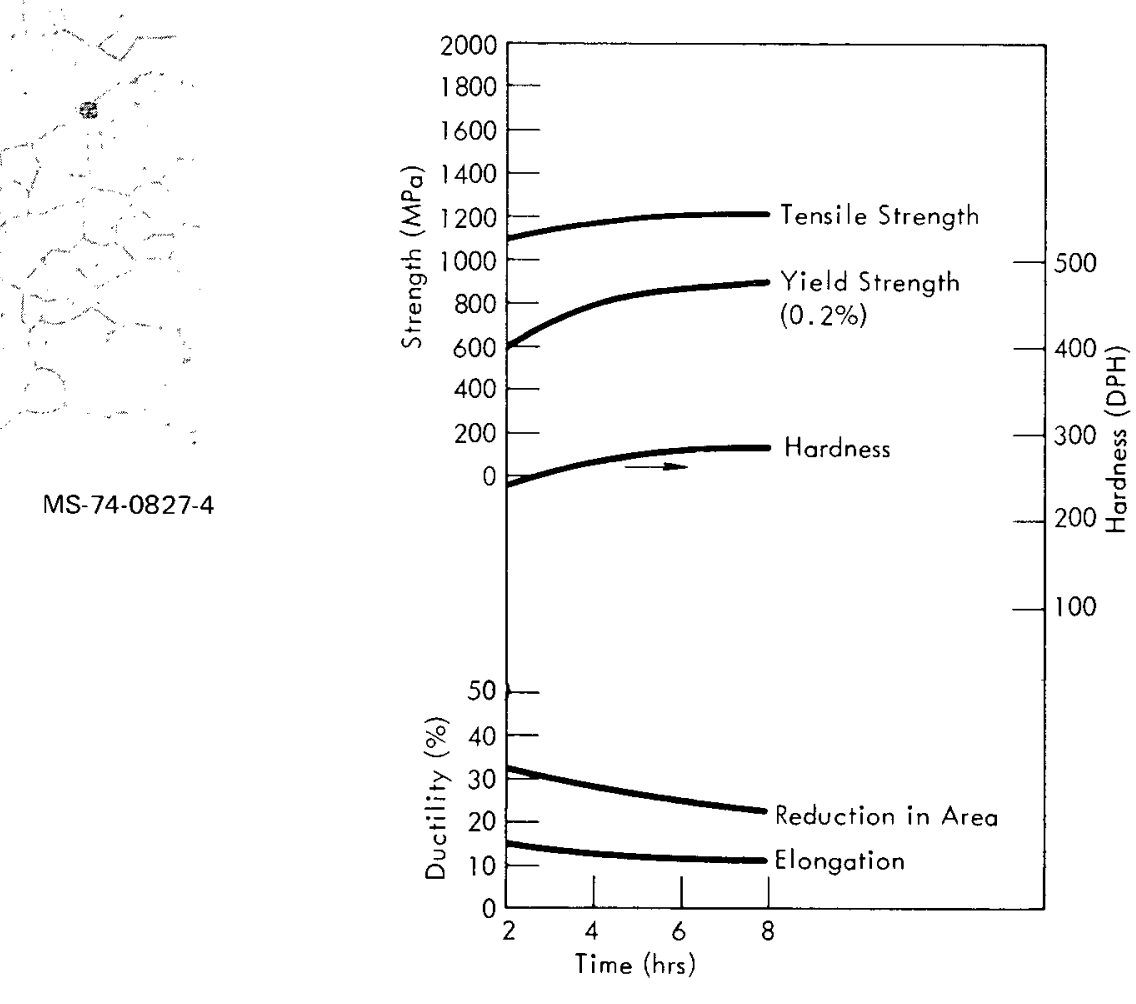

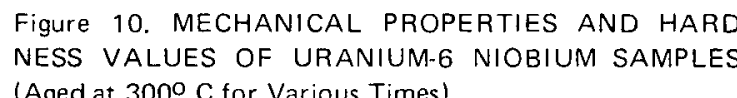



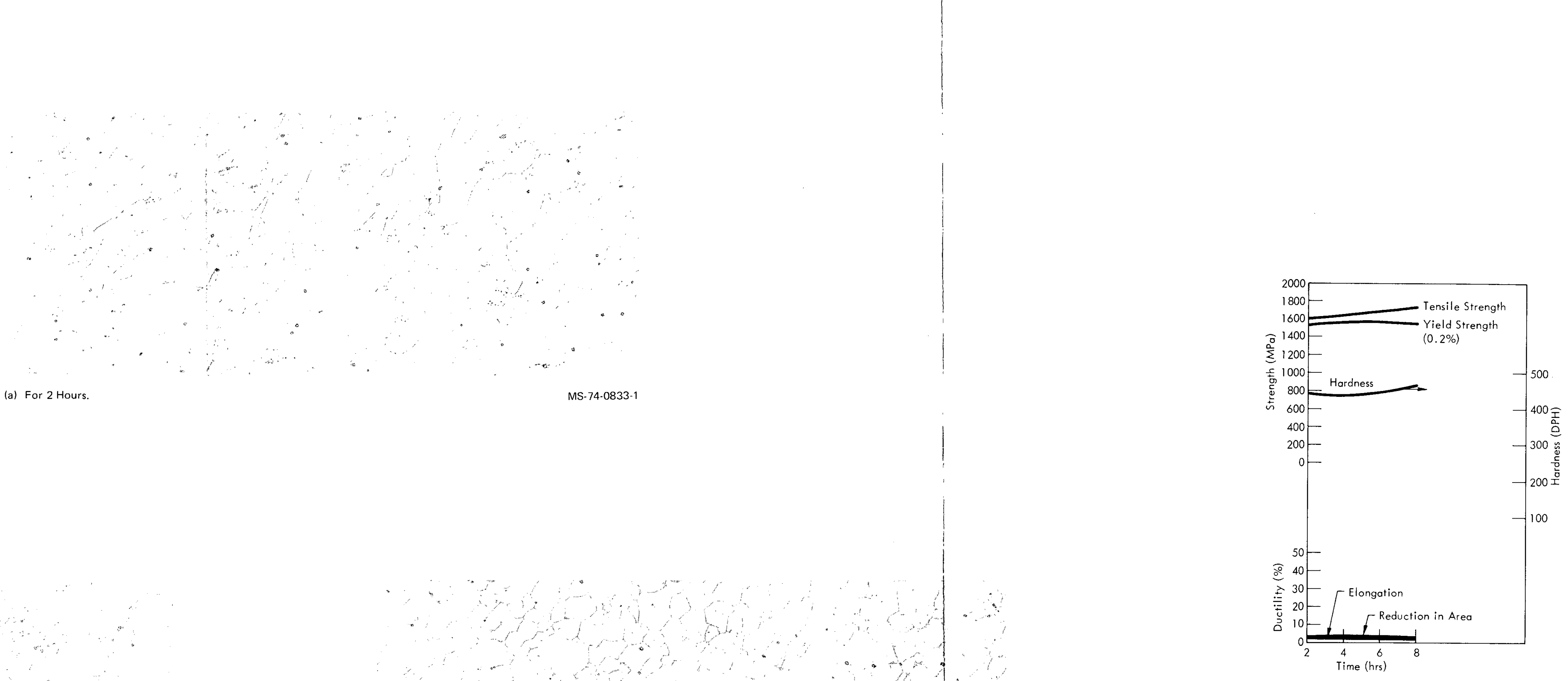

Figure 12. MECHANICAL PRRPERTIES AND HARD.
NESS VALUES OF UAANIUM-G NIOBIUM SAMPLES. NESS VALUES OF URANIUM-6
(Aged at $4000^{\circ} \mathrm{C}$ for Various Times) 

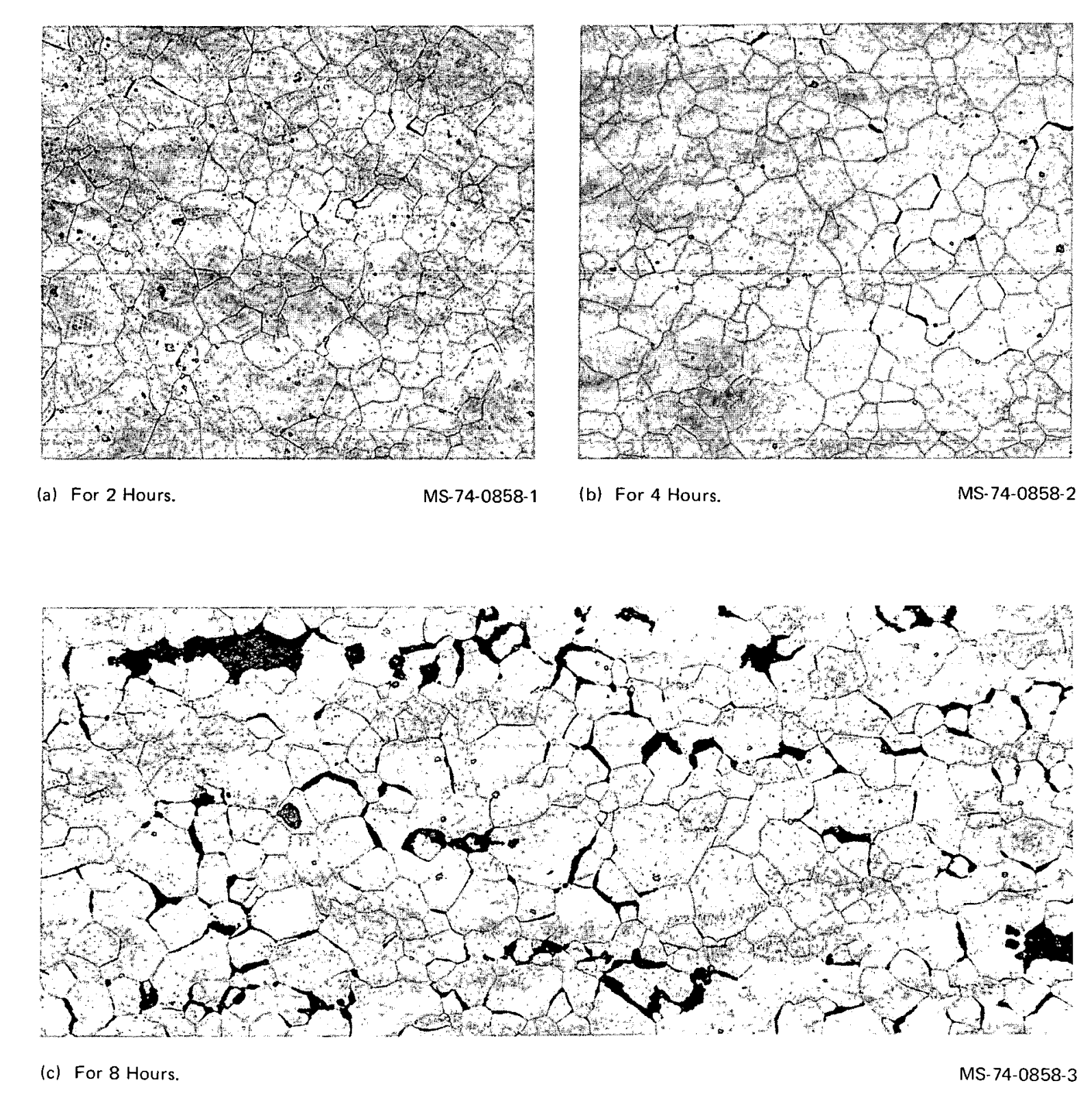

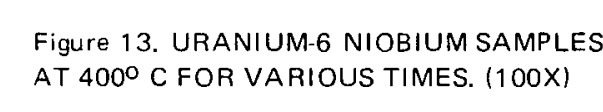

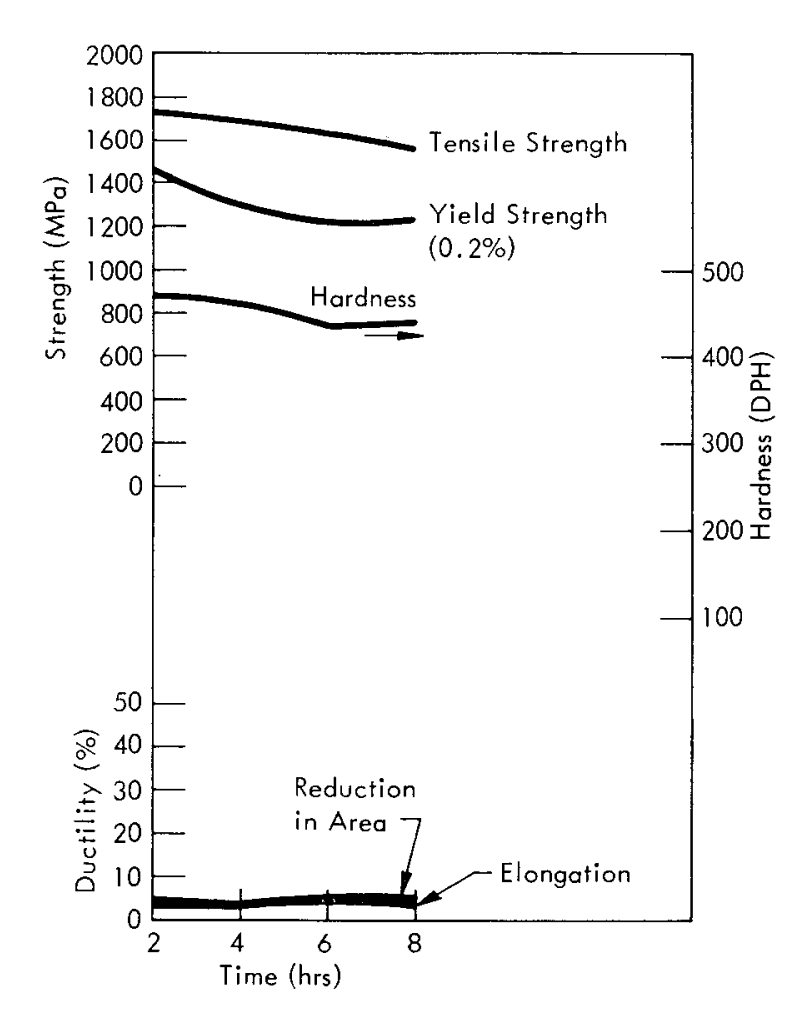

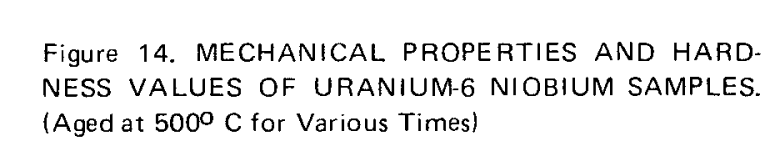

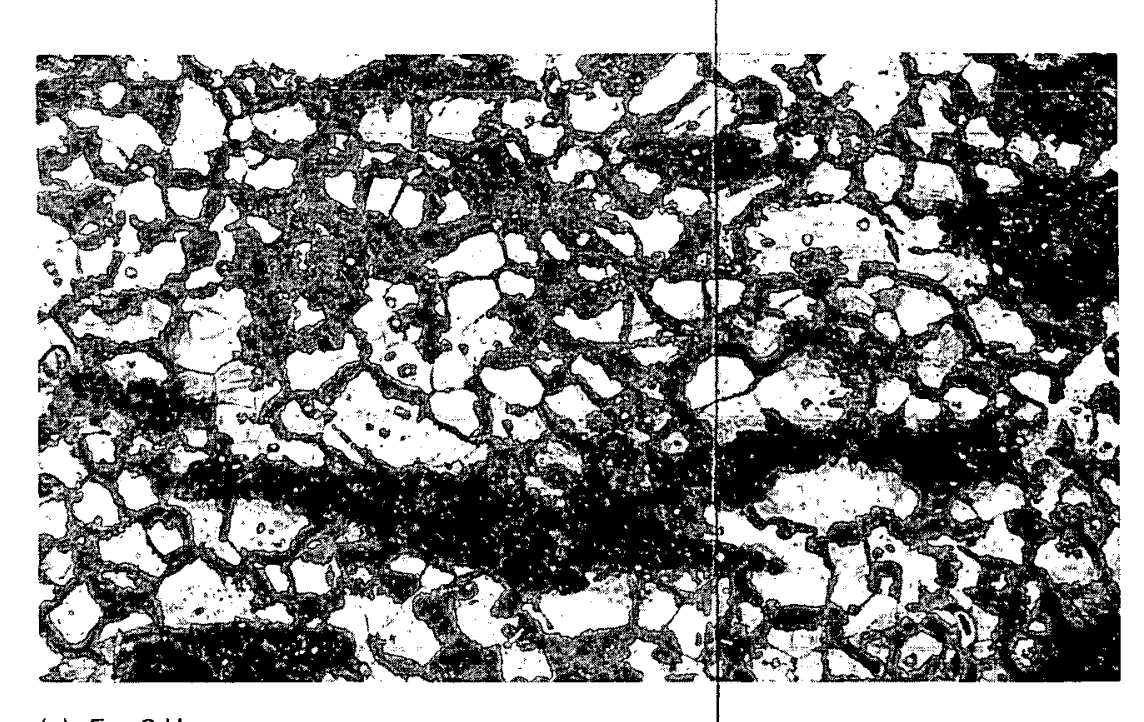

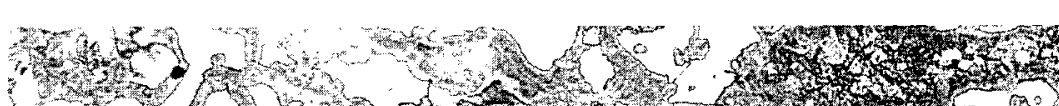

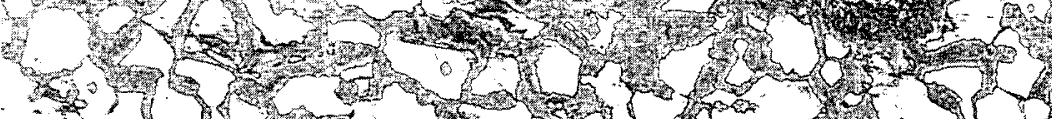

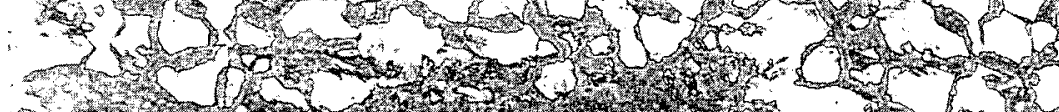

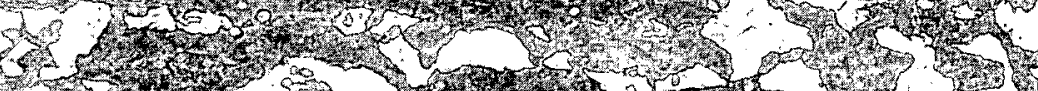

atr.t.

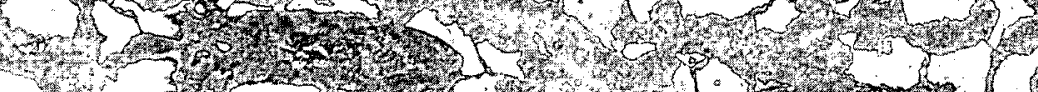
W (a) For 2 Hours (b) For 4 Hours MS-74-0858.5

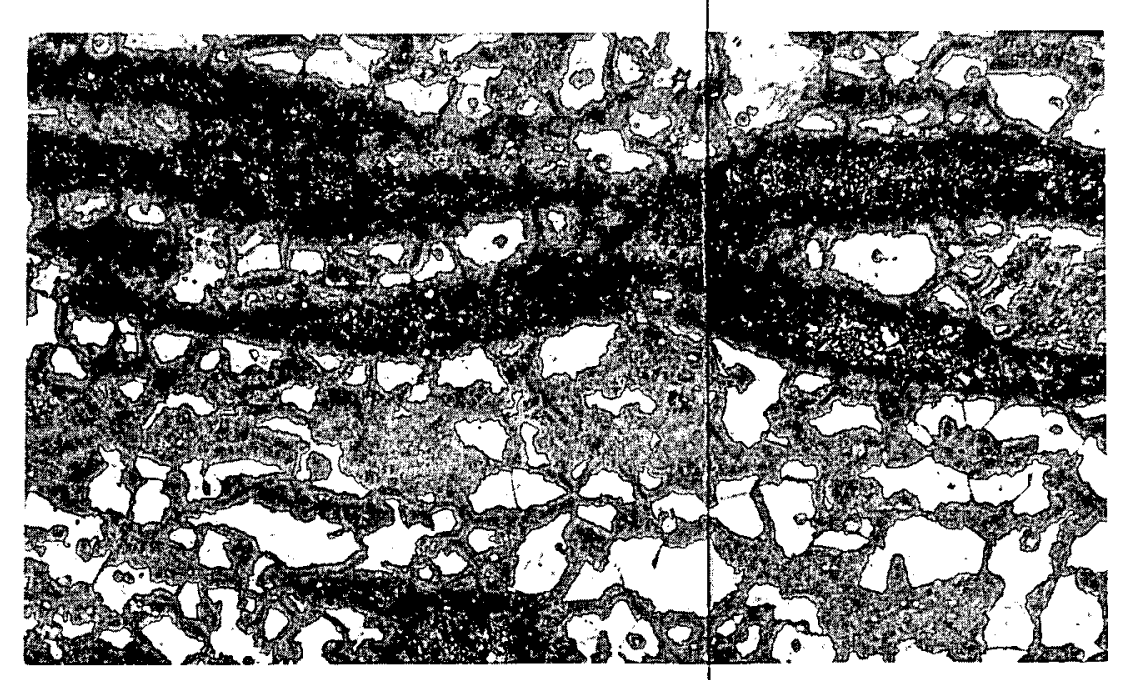
(10) Figure 15. URANIUM-6 NIOBIUM SAMPLES THAT WERE VACUUM-WATER QUENCHED FROM $8000^{C}$ C AND AGED AT $5000^{\circ}$ C FOR VARIOUS TIMES. (100X) 


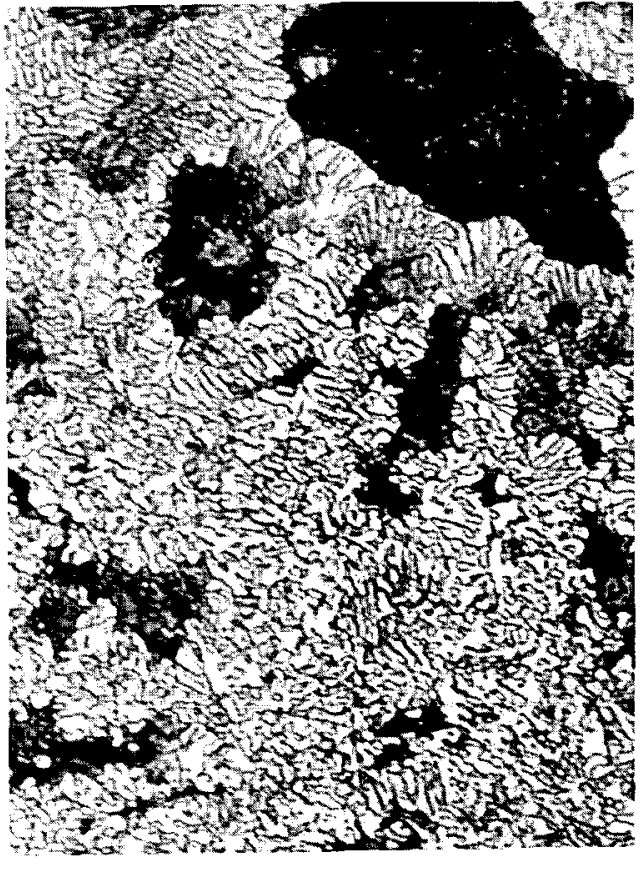

MS-73-1174-9

Figure 16. URANIUM-6 NIOBIUM SPECIMEN THAT WAS VACUUM-WATER QUENCHED FROM $800^{\circ} \mathrm{C}$ AND AGED AT $600^{\circ} \mathrm{C}$ FOR TWO HOURS.
The behavior of U-6 $\mathrm{Nb}$ on age hardening, if analogous to other similar systems, would involve an initial formation of solute-clusters or coherent precipitates which would cause strengthening, followed by a loss of coherency or decomposition to the equilibrium phase. It appears that the changes noted in the uranium-2 molybdenum system on aging are similar to those found in the U-6 Nb system. (3)

Results of the $X$-ray diffraction analysis are summarized in Table 1. The study showed that, at temperatures below $400^{\circ} \mathrm{C}$, the uranium-niobium alloy remains in the $a^{\prime \prime}$ transition phase over the times at temperature that were examined; but, a $500^{\circ} \mathrm{C}$ heat treatment results in transformation to the $a$-uranium phase. These results agree with those reported by Jackson, et al. (2) Although no $a$-phase transformation product was observed at the lower temperatures, peak broadening of the $a^{\prime \prime}$ peaks occurred with time at temperature. The $\gamma$-niobium phase was observed in four of the $a^{\prime \prime} \rightarrow a-U+\gamma-\mathrm{Nb}$ reactions; however, the $\gamma$-niobium phase observed in four of the

$200^{\circ} \mathrm{C}$-aged specimens probably results from banding/segregation which remained after the homogenization treatment given the alloy before quenching. Jackson, (4) Tangri and Chaudhuri, (5) and others have extensively studied the transformation phases of uranium-niobium alloys as a function of composition and temperature. However, they made no mention of any possible effects of aging on the lattice constants at these temperatures. The monoclinic $a^{\prime \prime}$ phase lattice parameters $(a, b, c$, and Angle $\gamma$ ) were determined to establish if any changes due to aging could be observed. Preliminary results from the $200^{\circ} \mathrm{C}$ specimens at aging times up to eight hours showed no observable trends in their lattice constants (Table 1). Lattice-parameter measurements on either the longer aging times at $200^{\circ} \mathrm{C}$ or higher temperatures were inconclusive due to the very broad peaks observed.

Tables 2 and 3 report the results of the SCC time-to-failure tests of bend specimens along with the strength properties of the various specimens. Electrical potentials were applied to vary the oxidizing conditions. Unaged and 150 and $200^{\circ} \mathrm{C}$-aged alloys did not fail under any of the test conditions. Table 4 gives a summary of the experimental conditions that did cause failure.

Static load tests were conducted on the unaged and 200, 300, and $600^{\circ} \mathrm{C}$-aged U-6 Nb alloys. In the static load tests, there were no applied potentials and the specimens were exposed to a $0.1 \mathrm{M} \mathrm{NaCl}$ solution ( $\mathrm{pH}$ of 4). These tests showed (Table 5) the brittle nature of the alloy aged at $300^{\circ} \mathrm{C}$ and the good resistance to cracking by the other alloys. The $600^{\circ} \mathrm{C}$-aged alloy withstood higher stresses, but the unaged and $200^{\circ} \mathrm{C}$-aged alloys showed good resistance to cracking, even at stresses near their yield points. 


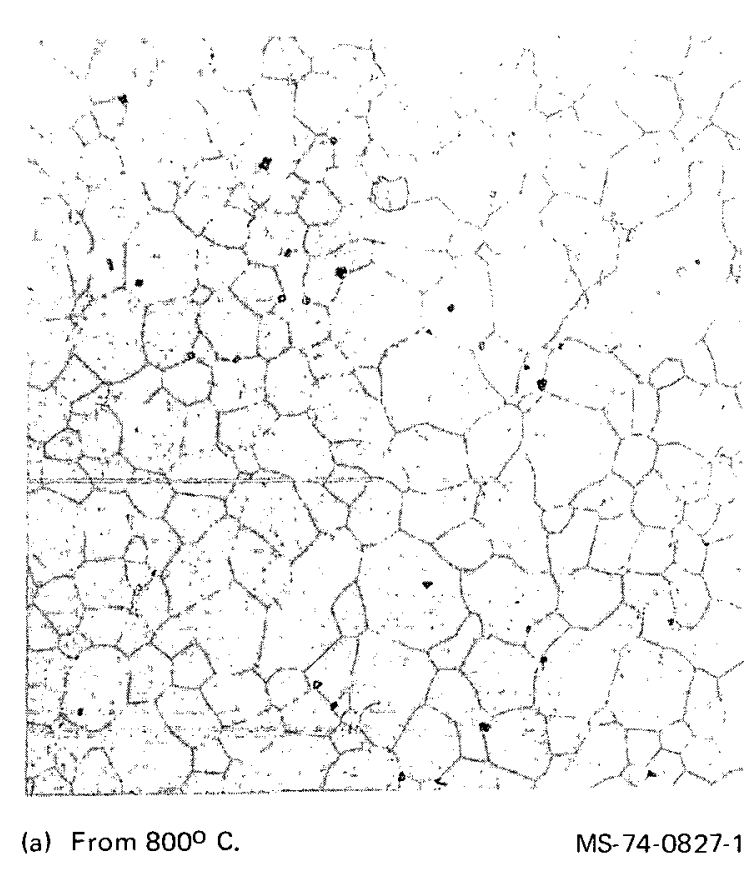

(b) From $850^{\circ} \mathrm{C}$.

ins-74-0827-8 (c) From $9000^{\circ} \mathrm{C}$

MS-74-0827-7

Figure 17. URANIUM.6 NIOBiUM SAMPLES THAT WERE VACUUM.WATER QUENCHED from VARIOUS
TEMPERATURES. (100X)
Table 1
X.RAY RESULTS From URANIUM-6 NIOBIUM ALLOY

\begin{tabular}{|c|c|c|c|c|c|}
\hline \multirow{2}{*}{$\begin{array}{c}\text { History } \\
(0 \mathrm{C})\end{array}$} & \multirow[b]{2}{*}{$X$-Ray Phase } & \multicolumn{4}{|c|}{ Lattice Parameters } \\
\hline & & & & $c$ & \\
\hline 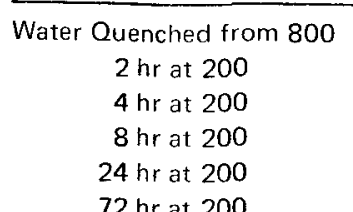 & 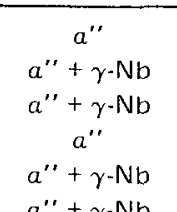 & 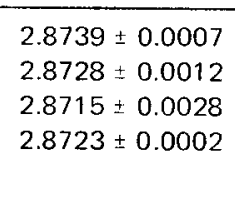 & 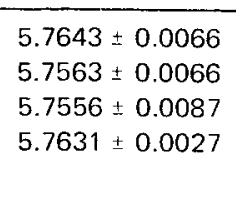 & 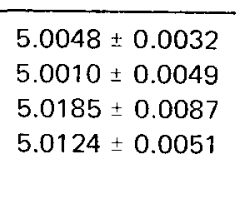 & 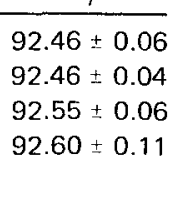 \\
\hline $\begin{array}{l}2 \text { hr a r a } 300 \\
4 \text { hra } 3000\end{array}$ & $\begin{array}{l}a^{\prime \prime} \\
a^{\prime \prime \prime(1)(1)}\end{array}$ & & & & \\
\hline 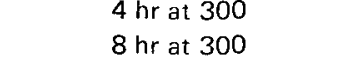 & $\begin{array}{l}a^{\prime \prime}(B)(B) \\
a^{\prime \prime}(B)\end{array}$ & & & & \\
\hline $\begin{array}{l}2 \text { hr r a } 400 \\
4 \text { hrat } 400\end{array}$ & $\begin{array}{l}a^{\prime \prime \prime}(B) \\
a^{\prime \prime}(\text { (B) }\end{array}$ & & & & \\
\hline 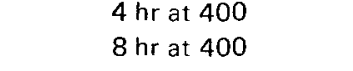 & $\begin{array}{l}a^{\prime \prime \prime}(\mathrm{B}) \\
a^{\prime \prime}(\mathrm{B})\end{array}$ & & & & \\
\hline $\begin{array}{l}2 \text { hr a } 5500 \\
4 \text { hra } 5500\end{array}$ & $\begin{array}{l}a+\gamma \cdot \mathrm{Nb} \\
a+\gamma \mathrm{Nb}\end{array}$ & & & & \\
\hline $\begin{array}{l}6 \text { h hr a } 5000 \\
8 \text { hat } 5500\end{array}$ & $\begin{array}{c}a+\gamma-\mathrm{Nb} \\
a+\gamma \mathrm{Nb}\end{array}$ & & & & \\
\hline
\end{tabular}

$$
\text { Table } 3
$$

TIME TO FAILURE OF GAMMA.OUENCHED URANIUMM N NIOBIUM
ALLOY SPECINENS INA A (DH, 4) AT DIFFERENT STRESSES UNDER AN APPLIED POTENTIAL OF $+200 \mathrm{mV}$
(Ag/AgCl Reterence Electrode, Rest Potential, $200 \mathrm{mV}$ )

\begin{tabular}{|c|c|c|c|c|c|}
\hline $\begin{array}{c}\text { AAing } \\
\text { Treat }\end{array}$ & $\begin{array}{l}\text { Applied } \\
\text { Stress } \\
\text { (MPa) }\end{array}$ & $\begin{array}{l}\text { Ultimitet } \\
\text { Tensie } \\
\text { Strenthe }\end{array}$ & 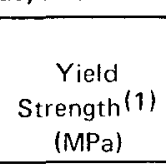 & Elongation (2) & $\begin{array}{l}\text { Time to to } \\
\text { failure } \\
\text { (min) }\end{array}$ \\
\hline $\begin{array}{c}\text { None } \\
1500^{\circ} \mathrm{C} .2\end{array}$ & $\begin{array}{l}210 \\
310\end{array}$ & $\begin{array}{l}808.9 \\
813.7\end{array}$ & $\begin{array}{l}136.4 \\
261.8\end{array}$ & $\begin{array}{l}32.0 \\
34.5\end{array}$ & $\begin{array}{c}n f(3) \\
n f\end{array}$ \\
\hline $\begin{aligned} 2000 \mathrm{C} \cdot & 2 \\
2500^{\circ} \mathrm{C} \cdot 2 & \end{aligned}$ & $\begin{array}{l}480 \\
240\end{array}$ & $\begin{array}{l}837.8 \\
899.1\end{array}$ & $\begin{array}{l}423 \\
600.1\end{array}$ & $\begin{array}{l}32.5 \\
26.9\end{array}$ & $\mathrm{nf}$ \\
\hline $30^{\circ} \mathrm{C}-3 \mathrm{hr}$ & $\begin{array}{l}690 \\
900\end{array}$ & $\begin{array}{r}899.1 \\
1112\end{array}$ & $\begin{array}{l}600.1 \\
7007\end{array}$ & $\begin{array}{l}26.9 \\
15.0\end{array}$ & $\begin{array}{c}10(4) \\
1(4)\end{array}$ \\
\hline 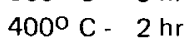 & 380 & 1430 & 1380 & $\begin{array}{l}1.0 \\
1.0\end{array}$ & $34(4)$ \\
\hline $10 \mathrm{hr}$ & $\begin{array}{l}1590 \\
1240\end{array}$ & $\begin{array}{l}\begin{array}{l}1430 \\
1435.2\end{array}\end{array}$ & $\begin{array}{l}\frac{1380}{1099.6}\end{array}$ & $\begin{array}{l}1.0 \\
9.8\end{array}$ & $\begin{array}{l}\text { (14) } \\
(5)\end{array}$ \\
\hline
\end{tabular}

(3) $25.4 \mathrm{~mm}$.
(3)
(I) sopecimens tailed in 1000 minutes

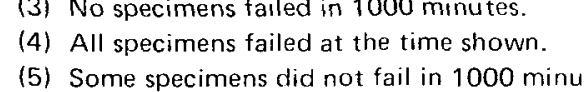

Table 2

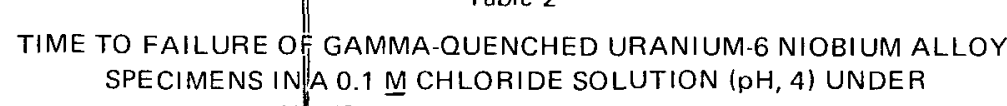
ANA APPLIED POCENTIAL OF $-200 \mathrm{mV}$
(Agg $\mathrm{mg}$, eference Electrode, Rest Potential, $380 \mathrm{mV}$ )

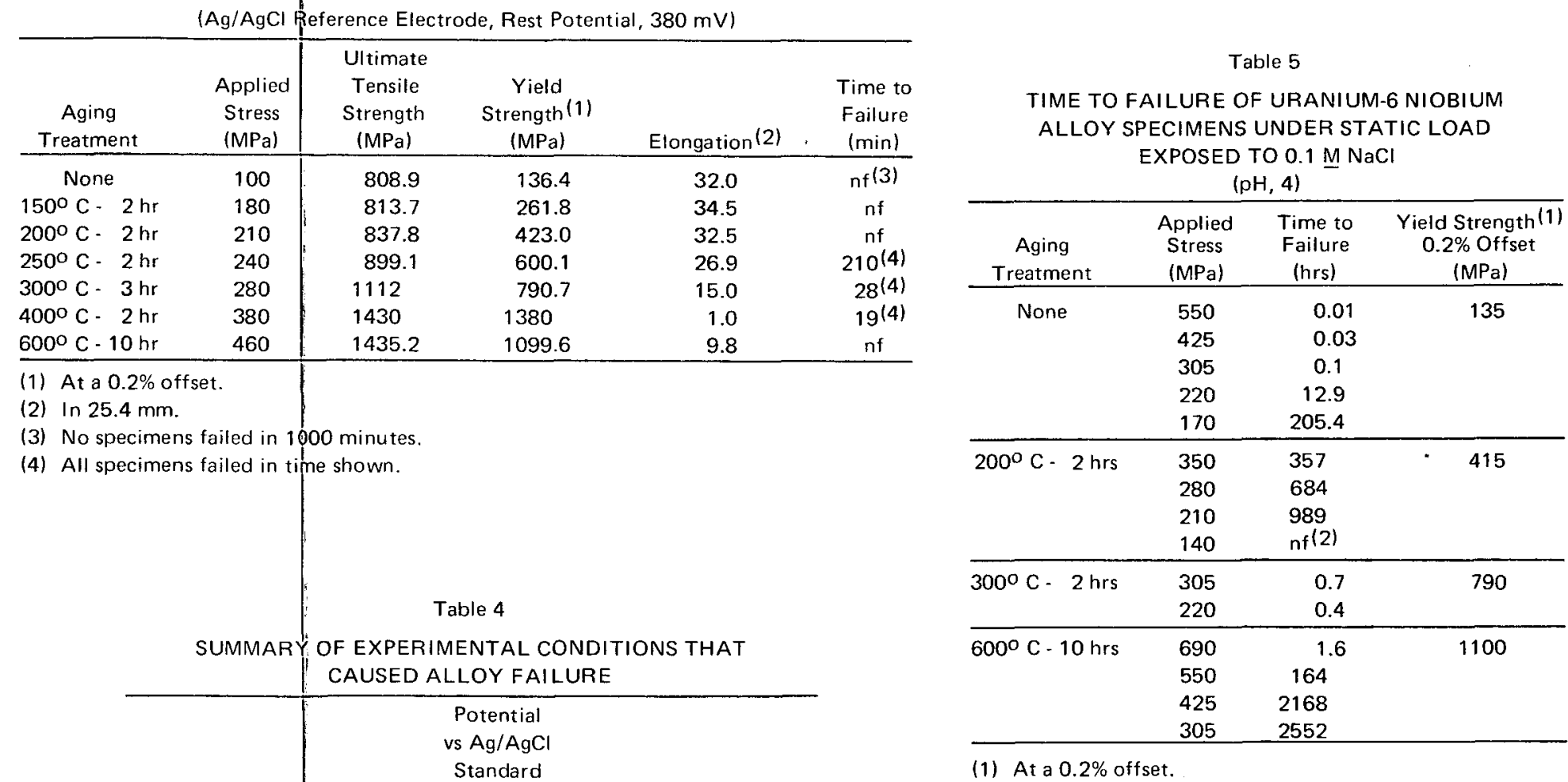

(1) At a $0.2 \%$ offset.
(2) No failure in over 40000 hours. 
The various bend specimen studies at many $\mathrm{pH}$ values and at a range of potentials showed, at $0.35 \%$ strain, that the unaged $\left(100 \mathrm{MPa}\right.$ stress) and $600^{\circ} \mathrm{C}$-aged (455 MPa stress) alloys did not fail at any applied potential or $\mathrm{pH}$ in chloride concentrations of $0.1 \mathrm{M}$ or below. However, the alloy aged at $300^{\circ} \mathrm{C}$ did fail in 0.1 and $0.01 \mathrm{M}$ sodium chloride solutions at various $\mathrm{pH}$ values and at a $0.35 \%$ strain ( $345 \mathrm{MPa}$ stress). There was little correlation between $\mathrm{pH}$ and time to failure for the $300^{\circ} \mathrm{C}$-aged specimens. Above the yield point $11.5 \%$ strain), all three alloys could be made to fail. The $1.5 \%$ strain was equivalent to 170,895 , and $1060 \mathrm{MPa}$ for the unaged, $300^{\circ} \mathrm{C}$-aged, and $600^{\circ} \mathrm{C}$-aged alloys, respectively. The failure was generally faster in basic solutions with the exception of a high $\mathrm{pH}$, such as 12.5 .

Figure 18 is an optical micrograph of an intergranular stress-corrosion crack in the unaged U-6 Nb alloy. The fracture surface (Figure 19) shows the grain facets, and some evidence of ductility could be seen. All the same features shown and discussed previously were seen for all the alloys aged up through $300^{\circ} \mathrm{C}$.

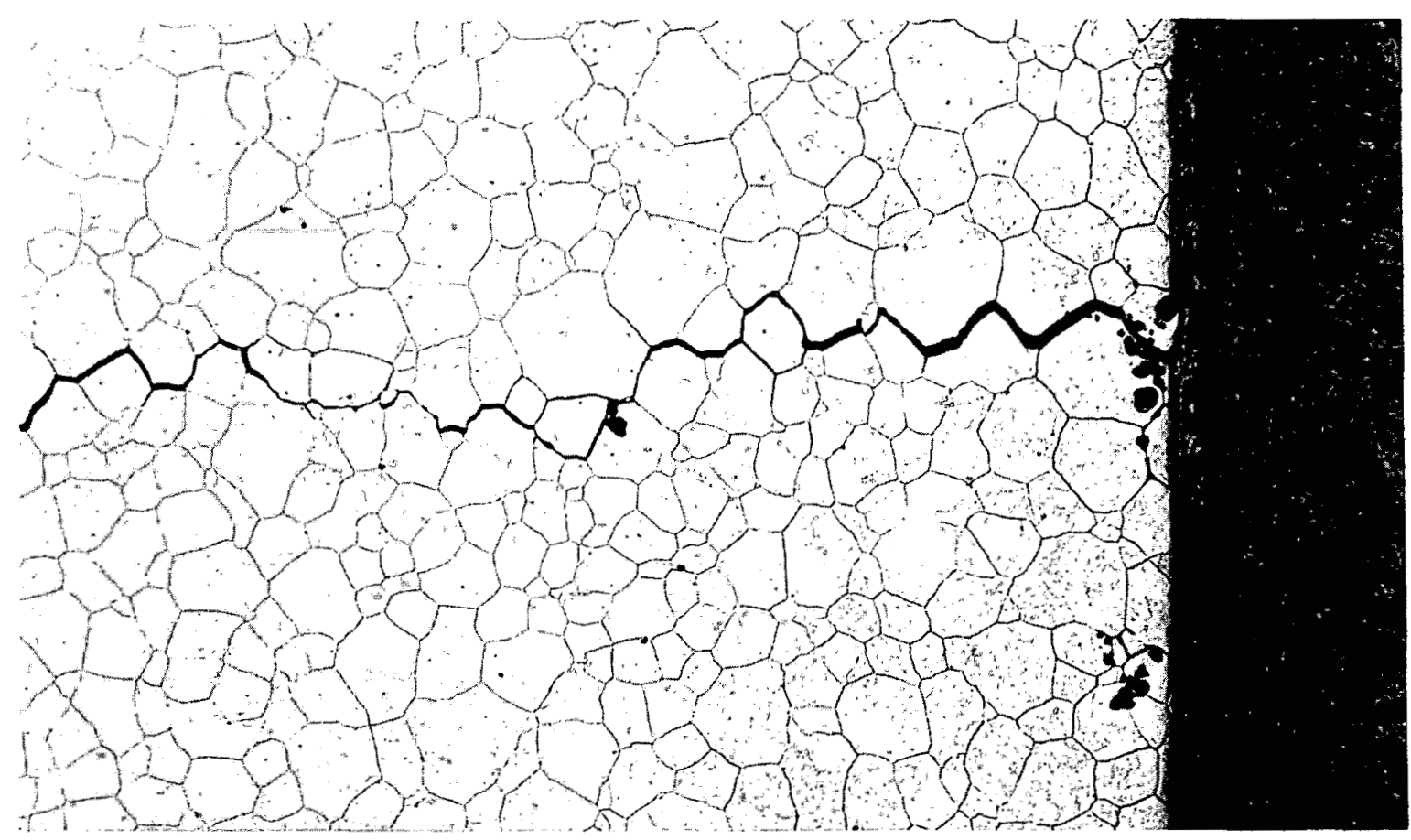

MS-73-1110-2 Figure 18. A STRESS-CORROSION CRACK IN AN UNAGED URANIUM-6 NIOBIUM ALLOY SPECIMEN THAT WAS EXPOSED TO A 0.01 M SODIUM CHLORIDE SOLUTION. (100X)

The two-phase structure of the $600^{\circ} \mathrm{C}$-aged specimen is seen in the scanning fractograph of Figure 20. The black phase (uranium) was brittle, and the fracture surface was not clearly defined due to the eutectoid structure.

The acoustic emission signals during the intergranular cracking were discrete and did not occur until a few minutes before failure. In the failure of the two-phase structures, much more noise was noted before failure. A similar alloy [uranium-7.5 niobium-2.5 zirconium (mulberry)] had a much "cleaner" fracture surface and similar acoustic properties. (6) 


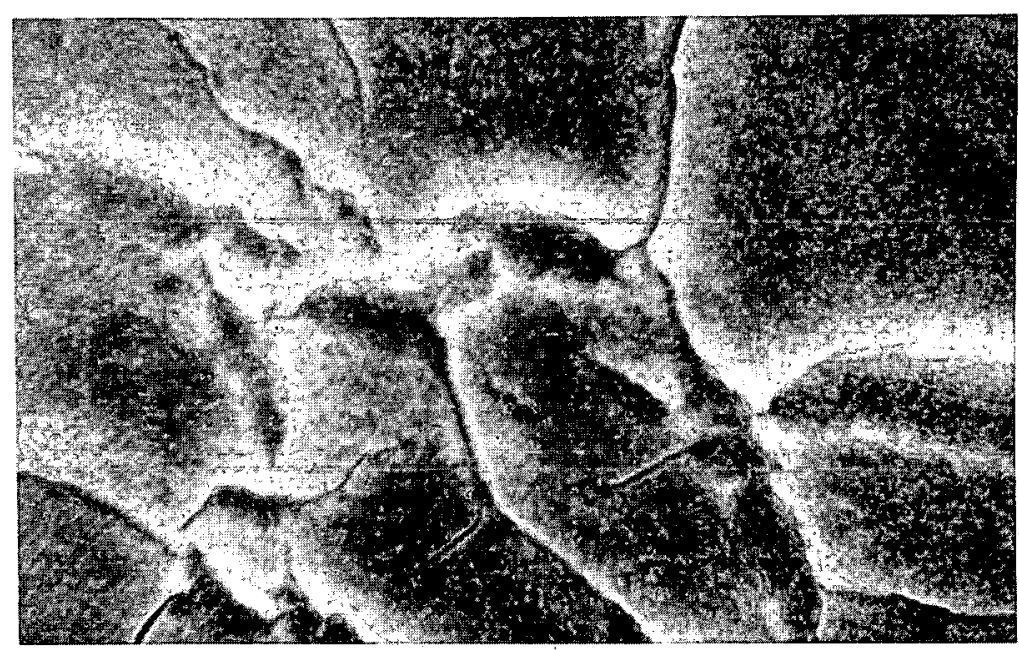

(a) At $10,000 \mathrm{x}$.

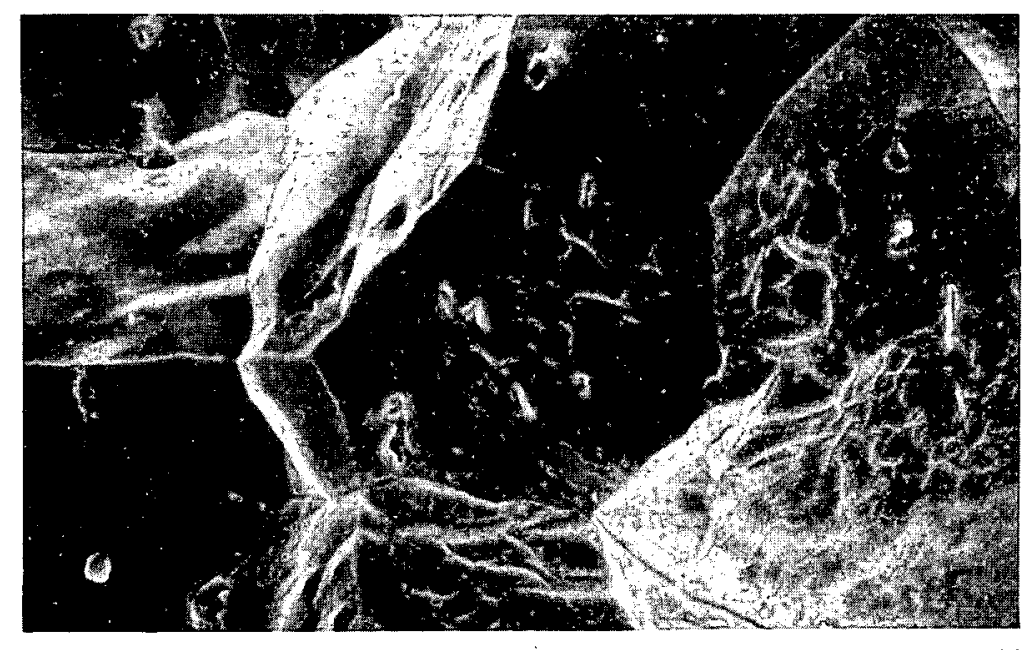

(c) At $1000 x$.

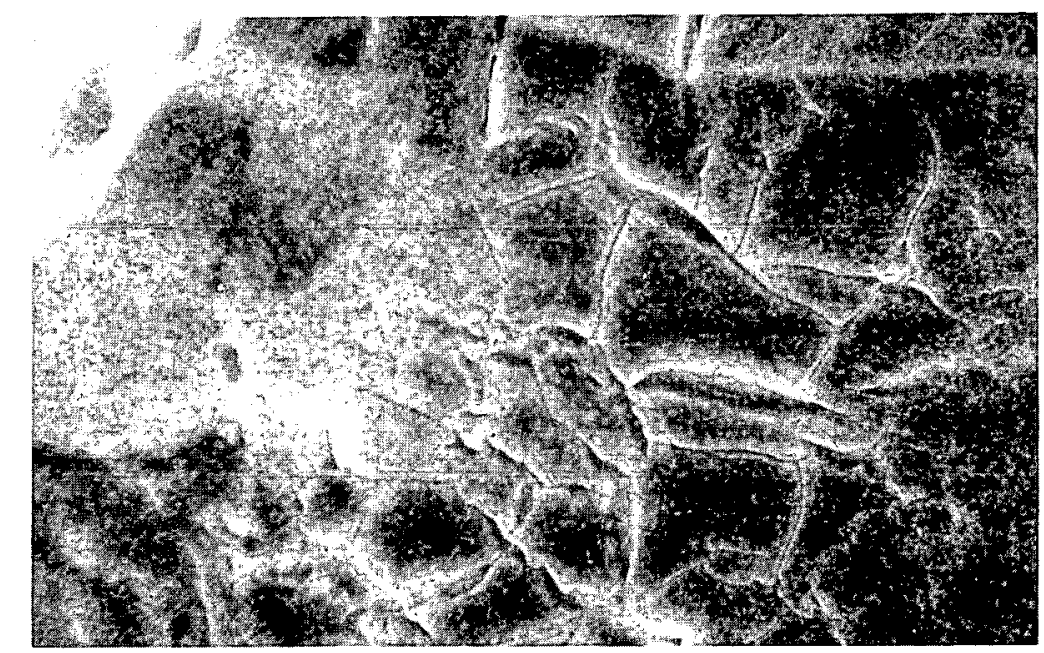

(b) At $3000 x$.

SM-41102

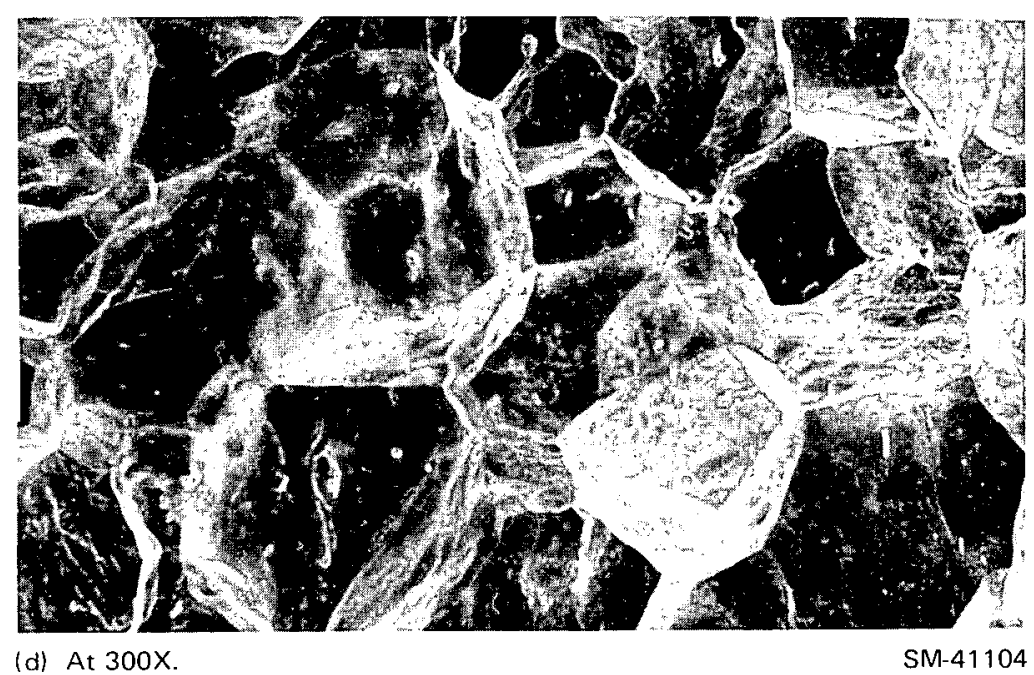

Figure 19. SCANNING ELECTRON MICROGRAPHS OF THE STRESS-CORROSION FRACTURE SURFACE OF AN UNAGED URANIUM-6 NIOBIUM ALLOY SPECIMEN THAT WAS EXPOSED TO A SODIUM CHLORIDE SOLUTION. 


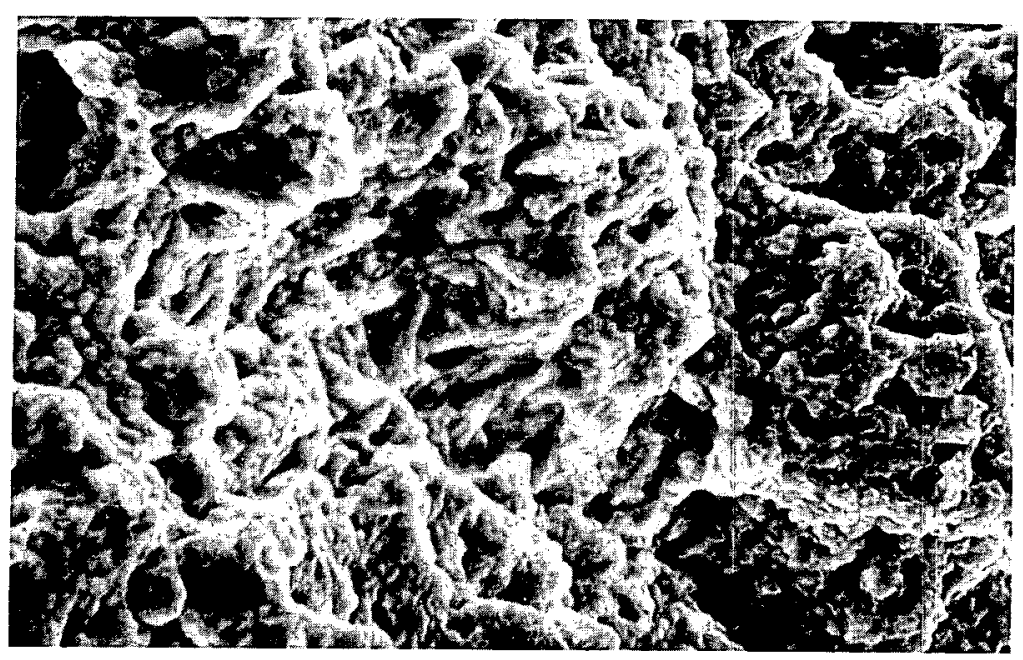

(a) At $3000 \mathrm{X}$.

SM-41085

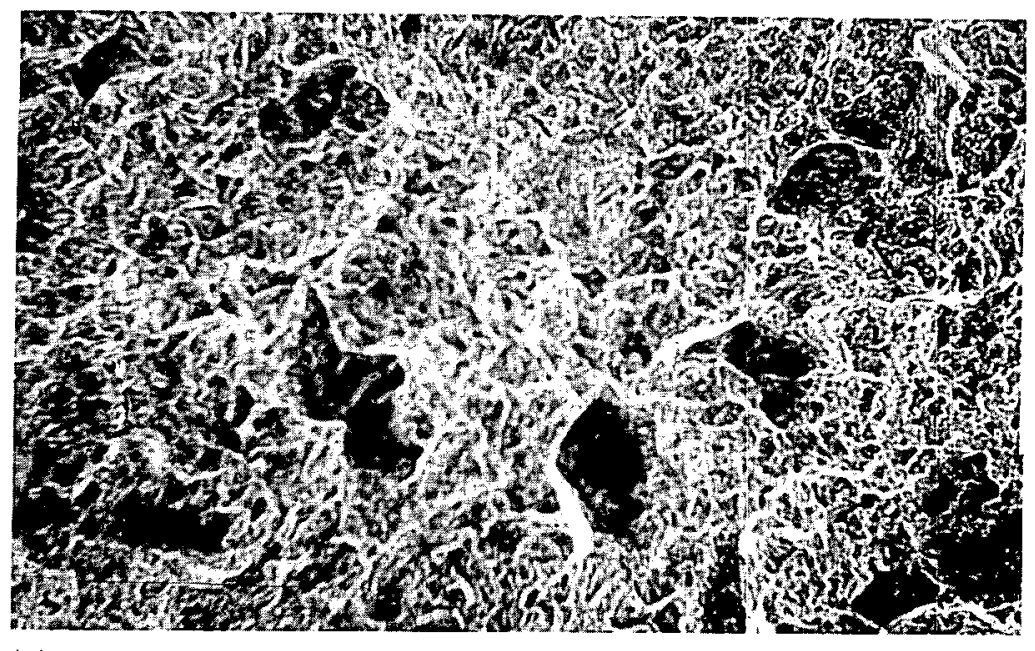

(b) At $300 \mathrm{X}$.

SM-41087

Figure 20. SCANNING ELECTRON MICROGRAPHS OF THE STRESSCORROSION FRACTURE SURFACE OF A URANIUM-6 NIOBIUM ALLOY SPECIMEN THAT WAS AGED AT $600^{\circ} \mathrm{C}$ AND EXPOSED TO A SODIUM CHLORIDE SOLUTION.

Certain aluminum alloys $(7)$ and mulberry (8) also exhibit similar stress-corrosion behavior to that shown for the U-6 Nb alloy. One explanation for the influence of the microstructure on the susceptibility to intergranular stress corrosion of high-strength aluminum alloys pertains to the grain-boundary precipitates and the precipitation-free zone along the grain boundaries. It was assumed that preferential flow would take place, and that the precipitation-free zones and preferential corrosive attack would occur along regions where plastic flow had taken place. (9) Recent work has shown that slip is concentrated in narrow bands across the grains and not in the precipitation-free zones. $(10-14)$ This observation would indicate that the overall distribution and nature of the precipitates within the matrix is most important because of their interaction with dislocations during plastic deformation. It has also been noted that a high susceptibility to SCC coincides with a large volume fraction of small coherent particles. 
A typical relationship between strength properties and SCC resistance used by Speidel (7) for high-strength aluminum alloys which undergo precipitation hardening, and used for mulberry by Weirick, (8) is noted in Figure 21. This relationship appears to be valid for the U-6 Nb system, and the temperature for each region as found in this experiment is included. The minimum time to failure noted in this study may or may not correspond to the maximum strength, but it appears to be close. When the minimum time to failure occurs at maximum hardness or strength, one explanation is that the difference in hardness between the grains and the precipitation-free zone is greatest at this point. 19,15$)$ However, many studies have indicated that the minimum life occurs considerably earlier in the aging process than the peak hardness and peak strength. (16-20) This study did not include detailed electron microscopy studies which would detect precipitation-free zones around grain boundaries and dislocation arrangements, but it is interesting to point out the similarities to other systems and perhaps stimulate work in these areas.

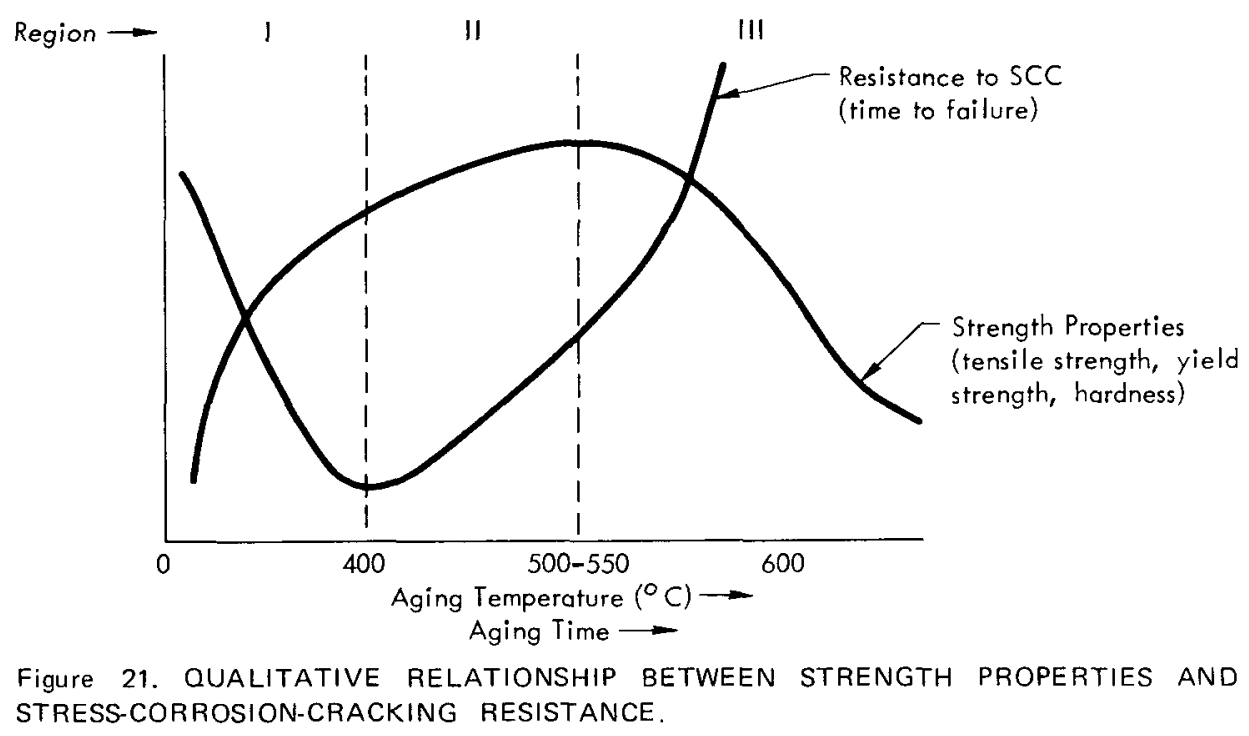

Potentiostatic polarization tests showed active dissolution of the alloys in chloride solutions of all $\mathrm{pH}$ values below about 12. Active/passive transitions were found at the higher $\mathrm{pH}$ values. In 0.1 and $0.01 \mathrm{M} \mathrm{NaCl}$ solutions having $\mathrm{pH}$ values from 4 to 9, the unaged and $300^{\circ} \mathrm{C}$-aged alloys showed the best corrosion resistance and the least susceptibility to pitting. The order of corrosion resistance is listed in Table 6. This investigation did not include a detailed study of what caused the mechanical-property changes on aging; however, the corrosion results do indicate that, prior to precipitation of the second phase $\left(400^{\circ} \mathrm{C}\right)$, the alloys aged at the highest temperature $\left(300^{\circ} \mathrm{C}\right)$ had the most corrosion resistance, with the corrosion resistance decreasing as the aging temperature decreased.

If it is assumed that clusters or coherent precipitates are formed during aging, and form in increased amounts with an increased aging temperature until they decompose to the equilibrium structure, then the general corrosion results reported here indicate that these clusters cause increased corrosion resistance. It is noted that there is no correlation between corrosion resistance and SCC for the U-6 Nb alloys. 
Tabie 6

ORDER OF CORROSION RESISTANCE OF URANIUM-6 NIOBIUM ALLOYS

\begin{tabular}{|c|c|c|}
\hline $\begin{array}{c}\text { Degree of } \\
\text { Corrosion Resistance }\end{array}$ & Alloy Treatment & $\begin{array}{c}\text { Structure } \\
\text { Characteristics }\end{array}$ \\
\hline \multirow[t]{6}{*}{ Most Corrosion Resistant } & As Quenched & No precipitates. \\
\hline & $300^{\circ} \mathrm{C}$ Aged & Largest amount of clusters. (1) \\
\hline & $250^{\circ} \mathrm{C}$ Aged & $\begin{array}{l}\text { Next largest amount of. } \\
\text { clusters. }(1)\end{array}$ \\
\hline & $200^{\circ} \mathrm{C}$ Aged & $\begin{array}{l}\text { Less clustering than the } 250^{\circ} \mathrm{C} \text { - } \\
\text { aged specimen. (1) }\end{array}$ \\
\hline & $150^{\circ} \mathrm{C} \mathrm{Aged}$ & $\begin{array}{l}\text { Less clustering than the } 200^{\circ} \mathrm{C} \text { - } \\
\text { aged specimen. (1) }\end{array}$ \\
\hline & $400^{\circ} \mathrm{C}$ Aged & Precipitated U-rich phase. \\
\hline Least Corrosion Resistant & $600^{\circ} \mathrm{C}$ Aged & $\begin{array}{l}\text { More precipitated } U \text {-rich phase } \\
\text { than the } 400^{\circ} \mathrm{C} \text {-aged specimen. }\end{array}$ \\
\hline
\end{tabular}

(1) Assumption.

Stress corrosion cracking is a combination of chemical and mechanical action. Since elongation and inverse-strength properties were more directly related to SCC susceptibility than general corrosion resistance, the mechanical effect is more of a factor for this alloy.

The as-quenched and 150 and $200^{\circ} \mathrm{C}$-aged alloys, which are single phase, are quite ductile and resistant to cracking in sodium chloride solutions. Their elongation values are all about the same. The alloys aged from 250 to $400^{\circ} \mathrm{C}$ are high-strength, brittle materials which were shown to be quite susceptible to $\mathrm{SCC}$ in salt solutions.

Resistance to SCC by the completely transformed two-phase alloy $\left(600^{\circ} \mathrm{C}\right.$ aged) can be attributed to its irregular grain structure since its elongation and corrosion resistance are both rather poor. Partially recrystallized mulberry has increased resistance to SCC by virtue of its irregular grain structure. ${ }^{(6)}$

\section{CONCLUSIONS}

There is a somewhat inverse relationship between strength properties and susceptibility to SCC by the U-6 Nb alloy. The as-quenched and 150 and $200^{\circ} \mathrm{C}$-aged alloys, whose elongation values were not appreciably changed on aging; and the two-phase alloy, which resulted from aging at $600^{\circ} \mathrm{C}$, are resistant to $\mathrm{SCC}$ in aqueous chloride solutions. The alloys aged from 250 to $400^{\circ} \mathrm{C}$ were quite susceptible to SCC. Ultimately, tensile strength and hardness peaked at an aging temperature of $500^{\circ} \mathrm{C}$ at 2 and 4 hours. On aging for 8 hours, the peaks were at an aging temperature of $400^{\circ} \mathrm{C}$. The elongation minimum was between aging temperatures of 400 to $500^{\circ} \mathrm{C}$. The as-quenched and $300^{\circ} \mathrm{C}$-aged alloy had the greatest resistance to general corrosion in aqueous chloride solutions, while the $600^{\circ} \mathrm{C}$-aged specimen had the least resistance. 


\section{REFERENCES}

(1) Jackson, R. J.; Uranium-Niobium Alloys: Annotated Bibliography RFP-2106; Dow-Rocky Flats; October 28, 1974.

(2) Jackson, R. J., Brugger, R. P., and Miley, D.V.; Tensile Properties of Gamma Quenched and Aged Uranium-Rich Niobium Alloys, RFP-933; Dow-Rocky Flats; June 2, 1967.

(3) Eckelmeyer, K. H.; "Aging Phenomena in Dilute Uranium Alloy", Proceedings of the Physical Metallurgy of Uranium Alloys Conference; Vail, Colorado; February $12-14$, 1974 (to be published).

(4) Jackson, R. J., Reversible Martensitic Transformations Between Transition Phases of Uranium-Base Niobium Alloys, RFP-1535; Dow-Rocky Flats; December 23, 1970.

(5) Tangri, K. and Chaudhuri, D. K.; J Nucl Matl, 15, p 278 (1964).

(6) Koger, J. W.; Variables Which Influence the Stress Corrosion Cracking of Uranium-7.5 Niobium-2.5 Zirconium, Y-1965; Union Carbide Corporation-Nuclear Division, Oak Ridge Y-12 Plant, Oak Ridge, Tennessee; January 28, 1974.

(7) Speidel, M. O.; "Interaction of Dislocations with Precipitates in High Strength Aluminum Alloys and Susceptibility to Stress Corrosion Cracking", Fundamental Aspects of Stress Corrosion Cracking; The Ohio State University, NACE (1969).

(8) Weirick, L. J.; "Effect of Heat Treatment Upon the Stress Corrosion of Mulberry (U-7.5 Nb-2.5 Zr)", Corrosion 31, pp 5 - 14 (1975).

(9) Thomas, G., and Nutting, J.; J Inst Met, 88, p 81 (1959-60). Thomas, G.; Electron Microscopy and Strength of Crysta/s, G. Thomas and J. Washburn, editors, p 849; John Wiley, New York (1963).

(10) Ryum, R., Haegland, B., and Lindtveit, T.; Z Metallkunde, 58, p 28 (1967).

(11) Hornbogen, E.; Z Metallkunde, 58, p 31 (1967).

(12) Speidel, M. O.; Proceedings of the Air Force Materials Laboratory 50th Anniversary Technical Conference on Corrosion of Military and Aerospace Equipment, Denver, Colorado, 23 - 25 May, 1967, AFML-TR-67-329, F. H. Meyer, editor (1967).

(13) Speidel, M. O., Phys Stat Sol, 22, K71 (1967).

(14) Holl, H. A.; Corrosion, 23, p 173 (1967).

(15) Parkins, R. N.; Metallurgical Rev, 9, p 201 (1964).

(16) Koster, W.; Aluminum, 34, p 694 (1958). 
(17) Pugh, E. N., PhD; RIAS Technical Report 65-7 (1965).

(18) Pugh, E. N., PhD; Thesis; University of Wales (1959).

(19) Klatte, H., Werkstoffe und Korrosion, 7 pp 545 and 708 (1956).

(20) Martin, A. J., Metal Ind, 21, pp 511 and 531 (1956). 


\section{Distribution}

Atomic International - Rocky Flats

Jackson, R. J.

Jiannetti, $E$.

Energy Research and Development

Administration - Oak Ridge

Hickman, H. D.

Leed, R. E.

Zachry, D. S., Jr

Lawrence Livermore Laboratory

Moon, D. W.

Robbins, J. L.

Root, G. S.

Woods, D. H.

Los Alamos Scientific Laboratory

Hockett, J. E.

Kirby, R. S.

Sandstrom, D.

Taub, J. E.

Oak Ridge Gaseous Diffusion Plant

Stief, S. S.

Wilcox, W. J., Jr

Oak Ridge National Laboratory

Brinkman, C. R.

Cathcart, J. V.

Martin, W. R.

McHargue, C. J.

Vandemeer, R. A.

Weir, J. R.

\section{Oak Ridge Y-12 Plant}

Ammons, A. M.

Bernander, N. K.

Burditt, R. B.

Burkhart, L. E.

Cadden, J. L.

Dodson, W. H.

Ellingson, R. D.

Ferguson, J. E. (5)

Fraser, R. J. 
Hemperly, V.C.

Jackson, V. C.

Jones, F.W.

Kahl, K. G.

Keith, A.

Kite, H. T.

Koger, J. W. (10)

Lundin, M. I.

Mills, J. M., Jr

Phillips, L. R.

Poore, M. W.

Schreyer, J. M.

Smith, H. F., Jr

Smith, R. D.

Snyder, W. B.

Stoner, H. H.

Tewes, W. E.

Tilson, F. V.

Townsend, A. B.

Waldrop, F. B.

Yaggi, W. J./Googin, J. M.

$Y-12$ Central Files (5)

$Y-12$ Central Files (master copy)

$Y-12$ Central Files (route copy)

$Y-12$ Central Files ( $Y$-12RC)

Zerby, C. D.

\section{Paducah Gaseous Diffusion Plant}

Levin, R. W.

\section{Sandia - Albuquerque}

Magnani, N. J.

McLaughlin, B.

Rohde, R. W.

Sallach, R. A.

Stephenson, L. L.

\section{Sandia - Livermore}

Adolphson, D. R.

Mote, M. W., Jr

Weirick, L.

In addition, this report is distributed in accordance with the category UC-25, Materials, as given in the USERDA Standard Distribution Lists for Unclassified Scientific and Technical Reports, TID-4500.

\section{US Army Materials and Mechanical}

Levy, M.

Rizzitano, F.J. Research Center - Watertown 